\title{
HYDROGEN PEROXIDE IN BIOCATALYSIS. A DANGEROUS LIAISON
}

\section{Karel Hernandez ${ }^{1}$, Angel Berenguer-Murcia ${ }^{2}$, Rafael C. Rodrigues ${ }^{3}$ and Roberto Fernandez-Lafuente ${ }^{1}$}

1: Departamento de Biocatalisis. Instituto de Catálisis-CSIC. Campus UAM-CSIC. Cantoblanco. 28049 Madrid (Spain).

2: Instituto Universitario de Materiales, Departamento de Química Inorgánica, Universidad de Alicante, Campus de San Vicente del Raspeig, Ap. 99 - 03080 Alicante (Spain)

3: Biocatalysis and Enzyme Technology Lab, Institute of Food Science and Technology, Federal University of Rio Grande do Sul, Av. Bento Gonçalves, 9500, P.O. Box 15090, ZC 91501-970, Porto Alegre, RS, Brazil.

* Corresponding author.

Prof. Dr. Roberto Fernández-Lafuente

Departamento de Biocatálisis. Instituto de Catálisis-CSIC.

C/ Marie Curie 2. Campus UAM-CSIC. Cantoblanco.

28049 Madrid (Spain).

e-mail: $\underline{\text { fl@icp.csic.es }}$ 


\section{Abstract}

Hydrogen peroxide is a substrate or side-product in many enzyme-catalyzed reactions. For example, it is a side-product of oxidases, resulting from the re-oxidation of FAD with molecular oxygen, and it is a substrate for peroxidases and other enzymes. However, hydrogen peroxide is able to chemically modify the peptide core of the enzymes it interacts with, and also to produce the oxidation of some cofactors and prostetic groups (e.g., the hemo group). Thus, the development of strategies that may permit to increase the stability of enzymes in the presence of this deleterious reagent is an interesting target. This enhancement in enzyme stability has been attempted following almost all available strategies: site-directed mutagenesis (eliminating the most reactive moieties), medium engineering (using stabilizers), immobilization and chemical modification (trying to generate hydrophobic environments surrounding the enzyme, to confer higher rigidity to the protein or to generate oxidation-resistant groups), or the use of systems capable of decomposing hydrogen peroxide under very mild conditions. If hydrogen peroxide is just a side-product, its immediate removal has been reported to be the best solution. In some cases, when hydrogen peroxide is the substrate and its decomposition is not a sensible solution, researchers coupled one enzyme generating hydrogen peroxide "in situ" to the target enzyme resulting in a continuous supply of this reagent at low concentrations thus preventing enzyme inactivation.

This review will focus on the general role of hydrogen peroxide in biocatalysis, the main mechanisms of enzyme inactivation produced by this reactive and the different strategies used to prevent enzyme inactivation caused by this “dangerous liaison”. 


\section{Outlook}

1. Introduction: hydrogen peroxide in biocatalysis and analytical protocols

2. Inactivation of enzymes by modification with hydrogen peroxide

3. Removal of hydrogen peroxide

3.1. Use of metals

3.2. Use of catalase and other enzymes

4. Keeping hydrogen peroxide concentration at low levels

5. Use of additives to improve the stability of enzymes in the presence of hydrogen peroxide

6. Genetic manipulation of enzymes to increase their stability in the presence of hydrogen peroxide

6.1. Site directed mutagenesis

6.2. Evolved enzymes

7. Physico-chemical modification of enzymes to increase their stability in the presence of hydrogen peroxide.

7.1. Immobilization

7.1.1. Enzyme stabilization versus hydrogen peroxide by decreasing the exposition of the susceptible groups to lower peroxide concentration

7.1.2. Improved rigidity of the enzyme

7.2. Chemical modification

Conclusions

References 


\section{Introduction: hydrogen peroxide in biocatalysis and analytical protocols}

Hydrogen peroxide is a simple and relatively mild oxidant reagent [1-3]. Aqueous $\mathrm{H}_{2} \mathrm{O}_{2}$ is a stable reagent with several advantages for oxidation applications. It furnishes $47 \%$ of its weight as oxidant, which is much more than other common oxidants such as $\mathrm{NaClO}, \mathrm{KHSO}_{5}$, and ROOH. Hydrogen peroxide is the ultimate "green" reagent because water and oxygen are the only by-products, so no inorganic salts are produced in its reaction [4].

From a biological perspective, it is recognized as substrate by many enzymes [5-48] (Table 1). 
Table 1: Some examples of reactions catalyzed by enzymes in the presence of hydrogen peroxide

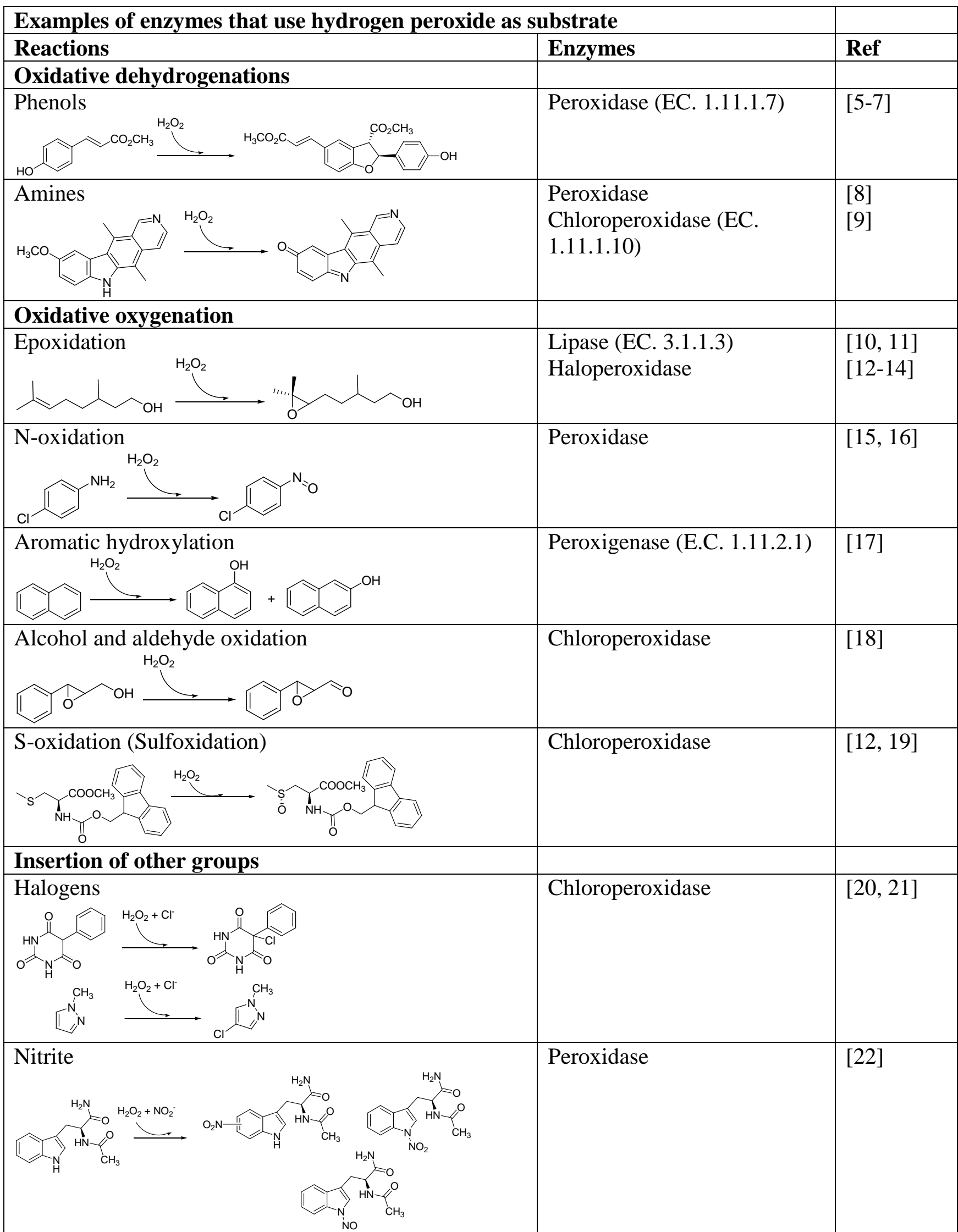




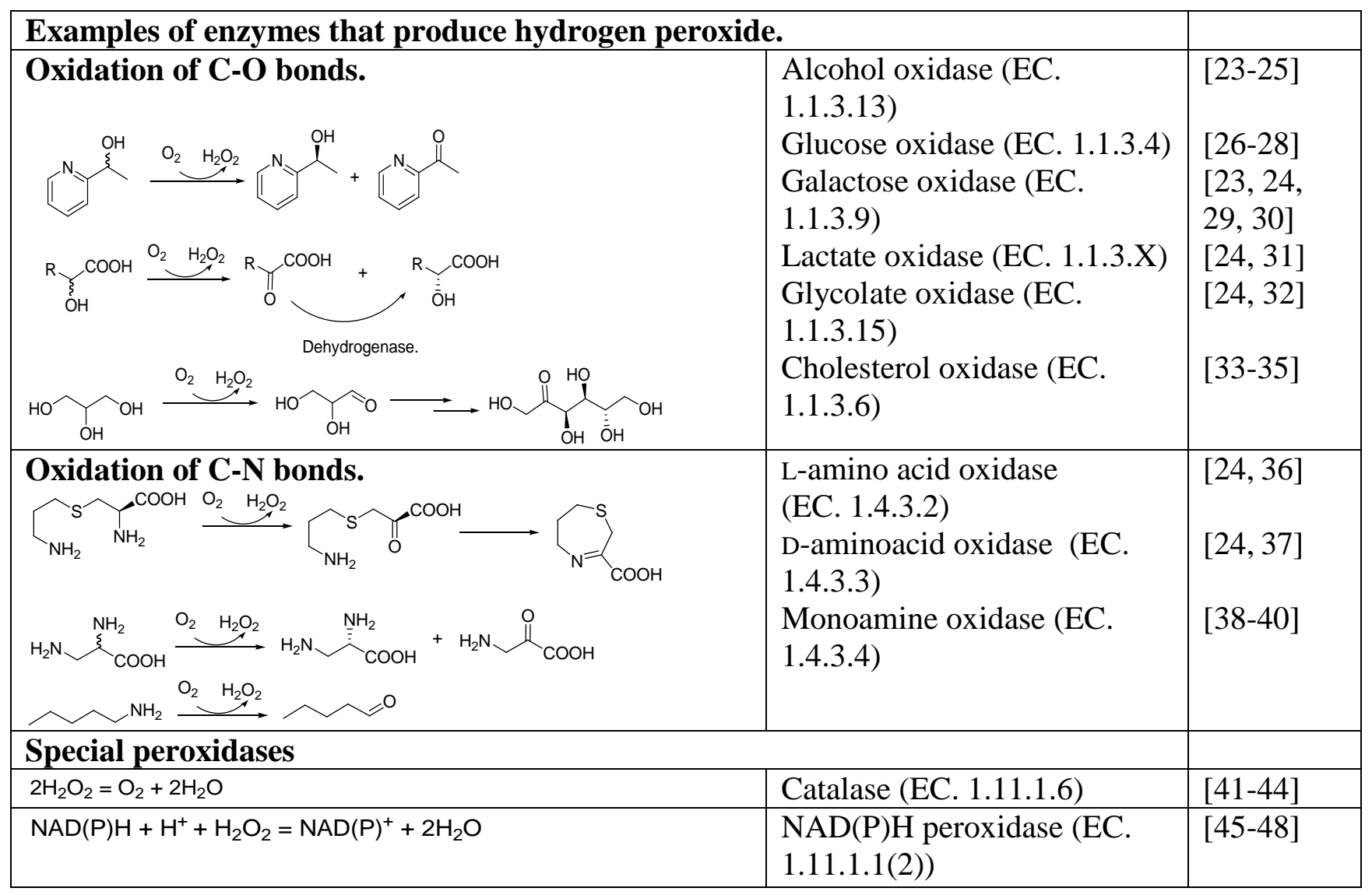

Among them, we would like to highlight peroxidases to perform oxidations [8], or catalases $[49,50]$, to decompose hydrogen peroxide yielding water and molecular oxygen. In many other examples, hydrogen peroxide is a side-product of the target reaction, like in the case of FADH-depending oxidases [51], where the cofactor is regenerated with molecular oxygen producing hydrogen peroxide. The production of hydrogen peroxide by these enzymes has been utilized in many examples as an electrochemical signal in the design of biosensors using oxidases [52, 53].

In vivo, the coupled actions of diverse enzymes keep the concentration of this compound under the levels which may compromise the viability of a given organism $[54,55]$. However, under in vitro conditions the situation becomes quite different; hydrogen peroxide may become accumulated reaching high concentrations or it may require to be added to the reaction medium. In fact, hydrogen peroxide is a compound capable of afecting the enzyme chemical structure, 
mainly at high concentrations [56]. It is able to modify many of the aminoacids of a protein (Arg, Pro, Lys, Met, Cys, Tyr, His, etc), even cleaving the peptidic bonds in some cases [57].

Thus, this reagent may play very different roles in biocatalysis and biosensor processes. Its production coupled to the target reaction produces a signal that makes the detection of the compound simple, making oxidases valuable as analytical tools. Unfortunately, the use of these oxidases as industrial biocatalysts to produce regioselective and enantiospecific oxidations may be hindered by the production of high concentrations of this reagent, which is able to inactivate the oxidase, and these high hydrogen peroxide concentrations will be formed if the process is performed under industrial concentrations of substrate [58].

In some cases, the produced hydrogen peroxide may cause the modification of the substrate or the product, like in the case of ketoacids production using amino acid oxidases [38, 59, 60]. The attack of this ketoacid by hydrogen peroxide may produce the oxidative decarboxilation of this compound. In some cases, this decarboxilation may be unwanted, e.g., if the desired reaction product is the ketoacid [60]. In other cases, this modification permits to obtain the target product as in the route to produce 7-aminocephalosporanic acid from cephalosporin C. D-amino acid oxidase produces Ketoadipyl-7-ACA, that after reacting with hydrogen peroxide produces glutaryl 7-ACA, which is the preferred substrate of the enzyme glutaryl acylase and has been the standard route to enzymatically produce 7-ACA until a cephalosporin acylase has been synthesized $[61,62]$. Even in this case, the presence of hydrogen peroxide becomes the bottleneck of the process and thus some routes avoiding this reagent have been proposed [62].

In other cases, this oxidant reagent may be used as substrate for peroxidases to obtain regioselective oxidations of really complex and interesting substrates [8]. Hydrogen peroxide may also be used to perform perhydrolysis catalyzed by hydrolases (mainly lipases) to produce peracids, a function quite far from that carried out by lipases in nature and one of the examples of the promiscuity of enzymes [10,63]. In all these cases, hydrogen peroxide is both substrate 
and inactivating reagent, and the reaction needs to be designed in a way that permits to have good reaction yields and rates, as well as high enzyme stabilities [64, 65].

Thus, hydrogen peroxide is a source of new possibilities in biocatalysis and biosensors and a risk to keep a stable system that may really maintain activity, stability, product concentrations and yields near those required by industry.

This review will try to show how this "dangerous liaison” causes enzyme inactivation, and it will show different strategies to diminish or even eliminate these negative effects. Obviously, the focus needs to be different when hydrogen peroxide is a substrate or a sideproduct of the reaction. In the latter case, the simplest way to reduce its negative impact on the enzyme stability will be to eliminate it, whereas in the first case this is not possible, as it is an enzyme substrate and may condition even the final yield of the reaction.

\section{Inactivation of enzymes by modification with hydrogen peroxide}

Chemical modification of proteins by hydrogen peroxide may reach many different groups, and therefore may have very negative effects on enzyme activity or stability (see Figure

1). The inactivation of proteins by oxidation has been reviewed by Stadtman and Levine [57]. Oxidation of proteins can lead to the hydroxylation of aromatic groups and aliphatic amino acid side chains, nitration of aromatic amino acid residues, nitrosylation of sulfhydryl groups, sulfoxidation of methionine residues, chlorination of aromatic groups and primary amino groups, and the conversion of some amino acid residues into carbonyl derivatives.

The direct reaction of proteins with hydrogen peroxide and other reactive oxygen species leads to the formation of protein derivatives or peptide fragments possessing highly reactive carbonyl groups (ketones, aldehydes). Proteins containing reactive carbonyl groups can also be generated by secondary reactions of primary amino groups from the lysine residues of proteins with reducing sugars or their oxidation products (glycation= glycoxidation reactions) [66-71]. Phenylalanine residues are oxidized to ortho- and meta-tyrosine derivatives [72-74]. Tyrosine 
residues may also react with hydrogen peroxide, yielding 3,4-dihydroxy (dopa) derivative [72, 75, 76], or bi-tyrosine cross-linked derivatives [73, 77-79]. Tryptophan residues are converted to the 2-, 4-, 5-, 6-, or 7- hydroxy derivatives, and also to $\mathrm{N}$-formylkynurenine and kynurenine [72, 80-82]. Methionine is readily oxidized to methionine sulfoxide by many different reactive oxygen species [83-85]. The oxidation of surface exposed methionines can thus serve to protect other functional essential residues from oxidative damage [83, 86]. Methionine sulfoxide reductases have the potential to reduce the residue back to methionine, increasing the scavenging efficiency of the system. Thus, interconversion of methionine and methionine sulfoxide can also be used as a tool to regulate the biological activity of proteins, through alteration of the catalytic efficiency and through modulation of the surface hydrophobicity of the protein $[83,87]$. However, the tendency of methionine to become easily oxidized is one of the main causes for enzyme inactivation in the presence of hydrogen peroxide. Enzymes inactivated by hydrogen peroxide via methionine oxidation include $\alpha 1$-antitrypsin [88] and D-amino acid oxidase $[89,90]$.

Modification of Cys to cysteic acid is also possible. For example, $\mathrm{H}_{2} \mathrm{O}_{2}$ can irreversibly inactivate the human brain type of creatine kinase via a two-stage process, via modification of CYS283, the catalytic residue [91]. Tyrosine phosphatases [92], porcine kidney betaine aldehyde dehydrogenase [93], and D-amino acid oxidase [90, 94] are inactivated in a similar way.

The situation becomes riskier if certain metals (e.g., iron or copper) are present in the reaction medium. The side-chains of amino acid residues of some proteins are readily oxidized by metal ion-catalyzed oxidation systems (Fenton reaction) [95-98]. Oxidation of the sidechains of lysine, arginine, proline, and threonine residues has been shown to yield carbonyl derivatives and histidine residues which are converted to 2-oxo-histidine. In studies with E. coli glutamine synthetase, it was found that amino acid residues located at metal binding sites on the 
enzyme are solely sensitive to metal-catalyzed oxidation by a site-specific mechanism [99-101]. Inactivation of astrocytic glutamine synthetase by hydrogen peroxide requires iron [102].

Oxidation can also lead to cleavage of the polypeptide chain by either the $\alpha$-amidation or diamide pathways [103]. In the $\alpha$-amidation pathway, the C-terminal amino acid of the fragment derived from the N-terminal region of the protein will exist as the amide derivative and the N-terminal amino acid of the fragment derived from the C-terminal portion of the protein will exist as $\alpha$-keto-acyl derivative. In contrast, the C-terminal amino acid of the fragment derived from the N-terminal portion of the protein via the diamide pathway will exist as the diamide derivative and the N-terminal amino acid residue of the peptide fragment derived from the C-terminal region of the protein will exist as the isocyanate derivative. It was also demonstrated that the oxidation of the glutamyl and aspartyl residues of proteins can also lead to peptide bond cleavage in which the $\mathrm{N}$-terminal amino acid of the C-terminal fragment will exist as the N-pyruvyl derivative $[57,103]$. Oxidation of prolyl residues might also lead to protein fragmentation [104] by a mechanism that involves oxidation of the proline residues to the 2pyrrolidone derivative [105]. Acid hydrolysis of this compound yields 4-aminobutyric acid. Thus, the presence of hydrolysates in the protein might be a measure of the degree of cleavage by the prolyl oxidation pathway.

In other cases the formation of cross-linked protein aggregates by reaction of groups formed on different enzyme molecules is detected, causing enzyme precipitation or/and inactivation. Oxidative modification of proteins can also give rise to intra- or inter-protein crosslinked derivatives by several different mechanisms, including: (a) direct interaction of two carbon-centered radicals [103]; (b) interaction of two tyrosine radicals; (c) oxidation of cysteine sulfhydryl groups [103, 106-108]; (d) interactions of the carbonyl groups of oxidized proteins with the primary amino groups of lysine residues in the same or with a different protein; (e) reactions of both aldehyde groups of malondialdehyde with two different lysine residues in the same or two different protein molecules; (f) interactions of glycation=glycoxidation derived 
protein carbonyls with either a lysine or an arginine residue of the same or a different protein molecule [69, 109, 110]; (g) interaction of a primary amino group of a lysine residue with protein aldehydes obtained via Michael addition reactions with the lipid peroxidation products (viz. 4-hydroxy-2-nonenal) [111, 112].

Furthermore, functional groups of proteins can react with oxidation products of some components of the medium. For example, polyunsaturated fatty acids and carbohydrate derivatives (glycation=glycoxidation) may produce inactive enzyme derivatives [57]. The generation of carbonyl derivatives occurs by many different mechanisms, the percentage of carbonyl groups in proteins is widely used as a marker of oxidative protein damage (even in in vivo studies).

\section{Removal of hydrogen peroxide}

\subsection{Use of metals}

Even though this review deals with the role and handling of hydrogen peroxide in biocatalysis, the issue has been addressed from a broad range of perspectives. Taking into account that the inactivation of enzymes in a bioreactor has already been described and corroborated by mathematical models $[113,114]$, the questions that remain at the end of the day for any scientist who is not an expert in biocatalysis are if hydrogen removal is possible in a bioreactor under very mild conditions and how to reach such a goal.

From an inorganic and/or materials science point of view, the number of options is considerable taking into account the available literature, since what is ultimately pursued is to accelerate the decomposition of an already labile compound. In this sense, the use of transition metal compounds (be it either salts or oxides) has been well established in the literature for many decades $[115,116]$. The development of inorganic materials or complexes that efficiently catalyze the decomposition of hydrogen peroxide has been the subject of intense studies [117119] and despite the fact that the catalysts found are, in most cases, far behind the performance 
of enzymes such as catalase, their robustness makes them interesting candidates for the development of bioreactors in which the removal or controlled generation of hydrogen peroxide might be an issue. Recent literature reports the use of different systems which decompose hydrogen peroxide with an efficiency which starts to resemble the performance of enzyme. These systems include bimetallic alloys [120], mixed-metal oxides [121], or even nanosized perovskite oxides [122]. In this sense, the combined use of mixed metal oxides (including perovskites) with noble metal catalysts has recently yielded excellent results [123].

Despite the existence of a number of promising systems for the removal of hydrogen peroxide using seemingly simple and robust catalysts, the question still remains whether it is feasible to integrate them into bioreactors in order to be able to run continuous cycles. The literature on this particular matter is noticeably scarce, namely showing examples of combined bioreactors in which an oxidase handles the transformation of the biocompounds fed in the reactor into the oxidized products and an inorganic catalyst decomposes the generated $\mathrm{H}_{2} \mathrm{O}_{2}$ to

enhance the bioreactor lifetime preventing the deactivation of the enzyme [124-126]. This should be regarded as a clear indicative that the design, planning, assembly, and operation of a continuous bioreactor based on enzymes and metals (be it either noble or transition metals) which should ensure a sufficiently high activity and lifetime still remains a challenge for the scientific community.

\subsection{Use of catalase and other enzymes}

Although metal-based catalysis may be an option to decompose hydrogen peroxide, the use of enzymes which able to perform this function has been studied more intensely, mainly due to the higher specificity of enzymes against undesired cross-reactions, and the unwanted effects that metal contamination may produce on some products.

In this sense, catalases are the preferred enzymes to destroy hydrogen peroxide, in many instances yielding water and oxygen [127]. These enzymes tend to be multimeric, with the 
problems on their stability that this fact raises [128], and may have an hemo group or some metal (i.e, $\mathrm{Mn}^{2+}$ ) as prostetic groups [129-131].

Glucose oxidase is the most used enzyme in combination with catalases, with the first examples to be found in the middle 20th century [132-142].

The co-immobilization of Aspergillus niger glucose oxidase with bovine liver catalase onto florisil (magnesium silicate-based porous carrier) permitted to improve the oxidase catalytic efficiency [143, 144]. In another research effort, catalase and oxidase were coimmobilized on non-porous glass surfaces using $\gamma$-aminopropyltriethoxysilane and polyethyleneimine as activators and glutaraldehyde as cross-linking agent [145]. Ultrafiltration membranes from acrylonitrile copolymer were chemically modified with different concentrations of hydrogen peroxide and used to immobilize both enzymes [146]. In a later report, glucose oxidase and catalase were also chemically immobilized onto different ultrafiltration polyacrylonitrile membranes and one microfiltration polyamide membrane [147]. Glucose oxidase coupled to the catalase on a polymer membrane adjacent to an anion-exchange membrane was used in another research effort [148]. Both enzymes were also trapped in calcium alginate beads [149]. Glucose oxidase and catalase were co-immobilized on polyethylenimine-coated cotton cloth by adsorption followed by cross-linking with glutaraldehyde [150]. In an elegant approach, the catalase-conjugated liposome encapsulating glucose oxidase was used to prevent oxidase inactivation by hydrogen peroxide [151, 152]. The reactivity of immobilized glucose oxidase-containing liposomes was considerably improved by incorporating the channel protein OmpF from Escherichia coli into the liposome membrane [153].

Glucose oxidase/catalase system may bring forth a certain antioxidant effect [154]. Thus, catalase has been combined with glucose oxidase to control the properties of some foods. Glucose oxidase-catalase acted as an anti- or pro-oxidant of model salad dressing containing $1.0 \%$ glucose depending on the concentration [155]. Glucose oxidase/catalase has an 
antioxidative effect in an oil/water emulsion packed in an oxygen-permeable plastic bag, even using polyunsaturated fatty acids [156, 157]. The color stability of a white grape juice was improved using glucose oxidase-catalase enzymes [158].

D-amino acid oxidase is another enzyme whose combination with catalase has been intended in many instances. The enzyme is inactivated by hydrogen peroxide, and the reaction product (an alpha-keto acid) is decarboxilated by this reagent. Considering that one of their main uses is the production of 7-cephalosporanic acid (7-ACA) from cephalosporin C, and that the second enzyme in the process (glutarayl acylase) recognizes glutaryl-7 ACA much better that alphaketo adiplyl-7ACA, this was a serious drawback in the design of the reaction [62]. In some cases, the excess hydrogen peroxide was destroyed in situ (most was consumed in the decarboxylation) by using catalase or some metal (e.g., manganese), or even both, immobilizing the enzyme on metal or metal oxide particles [159]. Later, after separation of the enzyme from the solution, additional hydrogen peroxide needs to be added to produce glutarayl-7ACA and make glutaral acylase efficient in the production of 7-ACA. Later, it was shown that, in complete absence of glutaryl-7ACA, glutarayl acylase can hydrolyze alpha-keto adipyl 7-ACA $[160,161]$. The key of the process was to remove the hydrogen peroxide as soon as possible to prevent the production of glutarayl 7-ACA. Thus, oxidase and catalase co-immobilization proved to be the most effective way to prevent accumulation of hydrogen peroxide (Figure 2), even though co-immobilization of several enzymes may raise some problems, it became necessary in this particular case [162]. This strategy has been established in the production of other alphaketo acids [163-167]. Moreover, the catalase-D-amino acid oxidase system has been used in the determination of racemized aminoacid after alkali treatment of proteins [168].

Many other enzymes that produce hydrogen peroxide as a side product have been stabilized using catalase: methane monooxygenase [169], pyranose 2-oxidase [170], carbohydrate oxidase from Microdochium nivale in the production of lactobionic acid [171, 172], 1-Aminocyclopropane-1-carboxyl oxidase [173], nicotinamide adenine dinucleotide 
phosphate oxidase complex [174], glycolate oxidase to produce glyoxylic acid [32, 175], oxalate oxidase [176], alcohol oxidase and formaldehyde dismutase in the conversion of methanol to formic acid [177], alcohol oxidase for glycolaldehyde production from ethylene glycol [178], L$\alpha$-glycerophosphate oxidase for the oxidation of L- $\alpha$-glycerophosphate to dihydroxyacetone phosphate [179], and milk xanthine oxidase [180].

In some instances, whole microorganisms with hyperexpressed catalase and oxidase were utilized as biocatalysts. Conidia of Penicillium variabile P16 containing glucose oxidase and catalase were immobilized in polyurethane sponge and used to produce gluconic acid [181]. A recombinant Hansenula polymorpha expressing the spinach glycolate oxidase and the Saccharomyces cerevisiae catalase $\mathrm{T}$ genes were used to convert glycolate into glyoxylic acid [182]. Trigonopsis variabilis induced for D-amino acid oxidase and catalase were immobilized by entrapment in polyacrylamide beads obtained by radiation polymerization [183].

One curious application of a catalase-oxidase system is the use of a galactose oxidase to generate a group in the sugar chain of a protein to immobilize it. This has been shown to yield the specific oxidation of a D-galactose present in the carbohydrate moiety of glucose oxidase from Aspergillus niger by galactose oxidase in the presence of catalase (48\% efficiency) [184]. This treatment did not change the activity of the enzyme. The oxidized enzyme was coupled to hydrazide derivatives of O- $\alpha$-D-galactosyl Separon H 1000 or of Sepharose 4B. Both solid supports were modified with adipic acid dihydrazide after their activation with galactose oxidase. Each immobilized preparation of glucose oxidase showed higher activity than the one reached by other immobilizing procedures.

Finally, the catalase/oxidase system has been used in many analytical tests for many decades. Glucose and galactose have been determined using glucose oxidase and catalase systems $[185,186]$.

A dual-amplification strategy of electrochemical signal based on the catalytic recycling of the product was developed for the antigen-antibody interaction by glucose oxidase - 
conjugated gold-silver hollow microspheres (coupled with an artificial catalase, Prussian blue nanoparticles), on a graphene-based immunosensing platform [187].

A conductometric biosensor was developed for the determination of short chain primary aliphatic alcohols based on the immobilization of alcohol oxidase from Hansenula sp. and bovine liver catalase in a photoreticulated poly(vinyl alcohol) membrane at the surface of interdigitated microelectrode [188].

Urinary oxalate determination based on immobilization of catalase and oxalate oxidase has been described [189]. Urinary oxalate is first decomposed by oxalate oxidase into carbon dioxide and hydrogen peroxide. The latter is then disproportioned into water and oxygen by the catalase model compound forming a colored compound, which was spectrophotometrically monitored.

Several methods for the quantitative detection of different compounds, eg., L-amino acids, sugars or alcohols in liquid media were developed by application of an automatic measuring unit including a fluid chip-calorimeter FCC-21 [190]. Different oxidases were covalently immobilized on controlled porous glass co-immobilized with catalase. Signal amplification could be achieved up to a factor of 3.5 with this configuration.

Enzymatic oxidation of benzidine and brompyrogallol red by hydrogen peroxide and inhibition of such process by phenols was studied using a photometric method [191]. Catalase and a mixture of oxidase enzymes obtained from potato water extract were tested as catalysts. The detection limit of phenol, resorcinol and pyrocatechol determination in tap and spring water using a well-established method was found to be $0.7,0.05$ and $0.02 \mathrm{mg} / \mathrm{dm}^{3}$, respectively

A new glucose-sensitive hydrogel, based on sulfonamide chemistry with covalently conjugated glucose oxidase and catalase, was synthesized and tested [192]. The pH-induced full swelling transition of the gel occurred in the range of $\mathrm{pH}$ 6.5-7.5. In a glucose concentration range of 0-300 $\mathrm{mg} / \mathrm{dl}$ in an isotonic phosphate buffered saline solution ( $\mathrm{pH} 7.4$ ), the $\mathrm{pH}$ inside the gel varied from $\mathrm{pH} 7.4$ to 7.2. At the same glucose concentration range, the gel showed 
reversible glucose dependent swelling without hysteresis from 12 to 8 , expressed in water (g)/polymer (g).

The toxicologically important peroxidase substrates bilirubin and aminopyrine can be determined by combination of immobilized glucose oxidase, horseradish peroxidase and catalase, forming the so-called enzyme sequence and enzyme competition electrodes [193]. Bilirubin and aminopyrine are determined in the 5-50 $\mu \mathrm{M}$ concentration range.

Glucose oxidase and catalase were immobilized in polyacrylamide gel around a platinum screen and used to measure the concentration of glucose in $0.1 \mathrm{M}$ phosphate buffer, $\mathrm{pH}$ 7.3, at $37^{\circ} \mathrm{C}$ [194]. This enzyme electrode produced a direct potentiometric signal with respect to a $\mathrm{Ag} / \mathrm{AgCl}$ reference electrode.

Other enzymes which are able to remove hydrogen peroxide have been used to stabilize the target enzyme. Thus, horseradish peroxidase and its reducing substrates, phenol-4sulfonic acid and 4-aminoantipyrine permitted the operarional stabilization of Hansenula polymorpha alcohol oxidase [195]. Vanadium chloroperoxidase from the fungus Curvularia inaequalis is a highly efficient catalyst for the production of singlet oxygen from hydrogen peroxide. In a mildly acidic aqueous environment the enzyme remains fully stable for 25,000 turnovers [196]. Thus, it has been proposed as an alternative to catalase and other enzymes to eliminate hydrogen peroxide.

\section{Keeping hydrogen peroxide concentration at low levels}

A suitable strategy to have a more stable biocatalyst, in reactions where hydrogen peroxide is the substrate, is to add the hydrogen peroxide in a stepwise form (Figure 3).

Using chloroperoxidase, an aliquot-by-aliquot addition of hydrogen peroxide in the presence of caffeic acid caused an increase in TTN to 171,000 from 135,000 at pH 4 [197].

In the lipase catalyzed epoxidation, the use of a controlled fed-batch reactor for maintaining $\mathrm{H}_{2} \mathrm{O}_{2}$ concentration at $1.5 \mathrm{M}$ resulted in increased productivity, up to 76 grams of 
product per gram of biocatalyst with higher retention of enzyme activity [65]. Further investigation included a multistage design that separated the enzymatic reaction and the saturation of the RME substrate with hydrogen peroxide into different vessels.

An elegant way to have this continuous and controlled supply of hydrogen peroxide is the use of a first enzyme that during catalysis produces hydrogen peroxide (e.g., an oxidase). Coimmobilization of glucose oxidase and peroxidase from Coprinus cinereus in a polyacrylamide matrix permitted the in situ production of hydrogen peroxide in the degradation of 2,6-dichlorophenol [198].

Chloroperoxidase and glucose oxidase have been co-immobilized on mesoporous solgel glass to reach this goal [199]. Porous polymersomes based on block copolymers of isocyanopeptides and styrene have been used to anchor enzymes at three different locations, namely, in their lumen (glucose oxidase), in their bilayer membrane (lipase B from Candida antarctica) and on their surface (horseradish peroxidase) [200]. The enzyme-decorated polymersomes were studied as nanoreactors in which glucose acetate was converted by lipase B from Candida antarctica to glucose, which was oxidized by glucose oxidase to gluconolactone in a second step. The hydrogen peroxide produced was used by horseradish peroxidase to oxidise 2,2'-azinobis(3-ethylbenzothiazoline- 6-sulfonic acid). Using glass microfluidic channels as microreactors, an invertase-glucose oxidase- soybean peroxidase trienzymic system was used to take sucrose and generate $\mathrm{H}_{2} \mathrm{O}_{2}$ for soybean peroxidase -catalyzed synthesis of poly(p-cresol) [201].

A slow release of hydrogen peroxide may be achieved by using suitable compounds. For example, alkene epoxidation based on the chemo-enzymatic perhydrolysis of carboxylic acids and esters has been optimized using Novozyme 435 (immobilized lipase B from Candida antarctica) and the complex urea-hydrogen peroxide [202]. Urea-hydrogen peroxide has the potential of releasing hydrogen peroxide in a controlled manner and thus avoids the need to add the aqueous hydrogen peroxide slowly to the reaction mixture. 


\section{Use of additives to improve the stability of enzymes in the presence of hydrogen peroxide.}

There are many investigations to find additives to preserve enzyme activity in the presence of hydrogen peroxide. In some cases, some electron acceptors have been used. For example, D-Glucose oxidase inactivation due to hydrogen peroxide was greatly reduced by adding the benzoquinone-hydroquinone system to the reaction system as an artificial electron acceptor [203]. In other cases, substitution of hydrogen peroxide by other oxidant reagents has permitted to increase enzyme stability. The use of tert-butyl hydroperoxide as oxidant instead of hydrogen peroxide using cloroperoxidase permitted to reach a turnover number of 600,000 (compared to less than 29,0000 using hydrogen peroxide), although the reaction was quite slow [197]. Presence of the spin traps N-tert-butyl- $\alpha$-phenylnitrone or 5,5'-dimethyl-1-pyroline-Noxide was effective in protecting the enzymes glutathione peroxidase and glutathione reductase against oxidation by UV, hydrogen peroxide/UV, and ozone [204].

The substrate, in some instances, may promote some stabilization effects. In the chloroperoxidase catalyzed oxidation of indole in tert-butyl alcohol/water mixtures, chloroperoxidase was stabilized towards oxidative destruction as long as indole was present in the reaction mixture but inactivation occurred in the absence of a reductant [205]. In contrast, chloroperoxidase was inactivated in water by hydrogen peroxide even when indole was present in the reaction mixture and the oxidant concentration was as low as $30 \mu \mathrm{M}$. Peroxidase is also protected by some reductant substrates [206]. Ascorbate peroxidase activity was rapidly lost in ascorbate-depleted medium, and protected by its electron donors, ascorbate, isoascorbate, guaiacol and pyrogallol, but not by GSH, NAD(P)H or ferredoxin [207].

Another option is the addition of antioxidant compounds to the system. Chloroperoxidase from Caldariomyces fumago was strongly stabilized by caffeic acid [197]. In 
the presence of this compound, the enzyme reached a total turnover number of 135,000 at $\mathrm{pH} 4$ and $4 \mathrm{mM}$ hydrogen peroxide, compared to 28,700 in the absence of antioxidant.

Amino acids have been used as additives in many instances to improve enzyme stability in the presence of hydrogen peroxide. The suicidal inactivation effect of horseradish peroxidase of hydrogen peroxide was reduced by using diverse amino acids [208]. Histidine, tyrosine and cysteine were added to the protein solution and horseradish peroxidase was completely protected against suicide inactivation. A very interesting observation was that peroxide-inactivated HRP could be recovered into a more active one in the presence of amino acids. Lignin proxidase from rot fungi was protected versus hydrogen peroxide inactivation when supplementing the culture medium with Trp [209]. Authors show that tryptophan and its derivative indole behave in the same way as veratryl alcohol in converting compound II, an oxidized form of lignin peroxidase, to ferric enzyme, thereby completing the catalytic cycle. Furthermore, tryptophan has been found to be a better substrate for lignin peroxidase than veratryl alcohol.

In another example, AMP deaminase was readily inactivated by an exposure to hydrogen peroxide and copper in permeabilized yeast cells [210]. Addition of ascorbic acid further enhanced the inactivation of the enzyme, suggesting the hydroxyl radical produced by the Fenton reaction is responsible for the inactivation of the enzyme. Addition of histidine caused an effective protection against the inactivation of AMP deaminase by hydrogen peroxide-induced hydroxyl radical.

Polymers have been used in other examples as stabilizers of enzymes against hydrogen peroxide. Porcine muscle lactate dehydrogenase was submitted to oxidation in the presence of metal ions and hydrogen peroxide, in the presence of a variety of compounds [211]. The best protecting agent was found to be the poly(ethyleneimine), followed by EDTA. Ammonium sulphate was an effective stabilizer during metal-catalyzed oxidation, while sorbitol, sucrose and hydroxyectoine provided moderate stabilization. Ectoine also stabilized against oxidation with 
hydrogen peroxide, as was poly(ethylene glycol), whereas sorbitol enhanced the rate of enzyme inactivation. The stability of the peroxidase from Coprinus cinereus versus oxidation was increased by addition of albumin (increased turnover number of naphthols oxidation 1.5-4 times) [212]. Poly-L-lysine, polyethylene glycol and polyethyleneimine also promoted a positive effect.

Different alcohols have also revealed themselves as interesting stabilizers versus oxidative processes. The causes for this stabilization have been attributed to different reasons. Subtilisin has been used in one of the examples. In the presence of hydrogen peroxide and borate, oxidation of a methionine residue adjacent to the active site to the sulfoxide form compromises subtilisin enzymatic activity [213]. Sucrose decreases the oxidation rate by limiting the accessibility of the borate-hydrogen peroxide complex to the methionine at the partially buried active site. The stabilization mechanism of sucrose is based on shifting the equilibrium of transiently expanding native conformations of subtilisin to favor the most compact states. Propylene glycol and glycerol produced an increase in the stability of alkaline protease from Bacillus clausii I-52 versus different reagents, also versus hydrogen peroxide inactivation [214].

Different additives, (mannitol, oleic, stearic and linoleic acid, n-butanol, and hydroperoxy octadecadienoic acid) stabilized lipoxygenase versus hydrogen peroxide [215]. The involvement of $\cdot \mathrm{OH}$ in the inactivation process is suggested by the ability of mannitol to prevent the loss of activity. This radical would be produced by reaction of $\mathrm{H}_{2} \mathrm{O}_{2}$ with the $\mathrm{Fe}$ (II) lipoxygenase. The most effective protection was displayed by hydroperoxy octadecadienoic acid, the reaction product of lipoxygenase with linoleic acid. This result could be explained by the conversion of the native enzyme into the $\mathrm{Fe}(\mathrm{III})$ lipoxygenase in the presence of hydroperoxy octadecadienoic acid; if the $\mathrm{Fe}(\mathrm{III})$ enzyme is not able to react with $\mathrm{H}_{2} \mathrm{O}_{2}$, an $\mathrm{OH}$ radical will not be produced. 
Some cations have been also used to increase enzyme resistance versus hydrogen peroxide. Turnover number and catalytic efficiencies for native horseradish peroxidase and $\mathrm{Ni}^{2+}$ horseradish peroxidase indicated that the catalytic activity and turnover number of the stabilized peroxidase by $\mathrm{Ni}^{2+}$ were about 1.5 times greater than the corresponding values for the native HRP [216]. Furthermore, while 53\% of active native horseradish peroxidase was depleted by hydrogen peroxide, $\mathrm{Ni}^{2+}$-HRP as a stabilized biocatalyst, showed an excellent resistance to the suicide-peroxide inactivation in the phenol removal process, in which only $6 \%$ of its active population was lost within 20 min and a phenol removal efficiency of about 98\% was observed.

\section{Genetic manipulation of enzymes to increase their stability in the presence of hydrogen}

\section{peroxide}

\subsection{Site directed mutagenesis}

The genetic replacement of certain aminoacids, sensitive to modification by hydrogen peroxide, by others more resistant to this modification, is a simple way to improve the enzyme resistance to hydrogen peroxide, utilized in many cases [217].

Replacement of Met by other residues insensitive to hydrogen peroxide has been proposed as a way to protect a protein against oxidative destabilization. A nice example of the effect of the substitution of Met residues on enzyme stability in the presence of hydrogen peroxide has been presented without the use of "actual” site directed mutageneis. This paper used an Escherichia coli strain transformed by the recombinant plasmid pIPD37 carrying the adk gene and grown under a substoichiometric concentration of methionine and an excess of norleucine. Under these conditions, the bacterium synthesizes $16-20 \%$ of adenylate kinase molecules having all 6 methionine residues replaced by norleucine [218]. Norleucine-substituted adenylate kinase shows structural and catalytic properties similar to the wild-type protein but exhibits a significantly higher resistance to hydrogen peroxide inactivation. The idea was also exemplified by the replacement of some key Met residues using a staphylococcal nuclease as a 
model protein, which ultimately permitted to improve enzyme stability [219]. In another example, the manganese peroxidase from Phanerochaete chrysosporium, which catalyzes the oxidation of $\mathrm{Mn}^{2+}$ to $\mathrm{Mn}^{3+}$, was stabilized versus hydrogen peroxide inactivation by conformational stabilization around the $\mathrm{H}_{2} \mathrm{O}_{2}$-binding pocket. By replacing oxidizable Met273 located near the pocket to a non-oxidizable Leu, hydrogen peroxide tolerance of the enzyme increased [220]. Furthermore, after treatment with $1 \mathrm{mM} \mathrm{H}_{2} \mathrm{O}_{2}$ where the wild-type is completely inactivated, full activity can be retained by engineering the Asn81, which might have conformational changes due to the pocket environment, to a non-bulky and non-oxidizable Ser.

In another example, the peroxidase from the cyanobacterium Anabaena sp. strain PCC7120 was submitted to site-directed mutagenesis to replace five Met residues by Ile, Leu, or Phe residues, in order to increase its resistance to hydrogen peroxide [221]. The heme cavity mutants M401L, M401I, M401F, and M451I had significantly increased hydrogen peroxide stabilities of 2.4-, 3.7-, 8.2-, and 5.2-fold, respectively. Surprisingly, the M401F and M451I retained $16 \%$ and $5 \%$ activity at $100 \mathrm{mM} \mathrm{H}_{2} \mathrm{O}_{2}$, respectively,

Another interesting example was the improvement of nattokinase stability versus oxidative inactivation. It is a bacterial serine protease with strong fibrinolytic activity and it is used as cardiovascular drug. In medical and commercial applications, however, it is susceptible to chemical oxidation, and subsequent inactivation or denaturation. This oxidative stability of Nattokinase was substantially increased by optimizing the amino acid residues Thr 220 and Met 222, which were in the vicinity of the catalytic residue Ser 221 of the enzyme. Two nonoxidative amino acids (Ser and Ala) were introduced at these sites using site-directed mutagenesis. M222A mutant was found to have a greatly increased oxidative stability compared with wild-type enzyme and it was resistant to inactivation even when using $1 \mathrm{M}$ hydrogen peroxide, whereas the wild-type enzyme was inactivated by $0.1 \mathrm{M}$ of this reagent $(\mathrm{t} 1 / 2=11.6 \mathrm{~min})$. The mutant $\mathrm{T} 220 \mathrm{~S}$ also showed an obvious increase in stability versus oxidation. Molecular dynamic simulations on wild-type and T220S mutant proteins suggested 
that a hydrogen bond was formed between Ser 220 and Asn 155, and the spatial structure of Met222 was changed compared with the wild-type.

N-Carbamoyl D-amino acid amidohydrolase (D-NCAase) from Agrobacterium radiobacter is another enzyme sensitive to oxidative damage by hydrogen peroxide [222]. Each of the nine methionine residues in the enzyme was substituted with leucine by site-directed mutagenesis. Except for two mutants (Met5Leu and Met31Leu) with similar activities, seven mutants (Met73Leu, Met167Leu/Met169Leu, Met184Leu, Met220Leu, Met239Leu, Met244Leu, and Met239Leu/Met244Leu) were found to have reduced activities. In the presence of hydrogen peroxide, three mutants (Met239Leu, Met244Leu, and Met239Leu/Met244Leu) with substitutions of highly solvent-accessible methionines by leucines retained their activities. The other mutants were also considerably more resistant to chemical oxidation than the wildtype enzyme.

In another example, the methionine residues at positions 17, 104, 208, 214, 292, 315, 324, and 446 in the primary amino acid sequence of a truncated Bacillus sp. TS-23 $\alpha$-amylase (His6-tagged) were changed to oxidative-resistant leucine by site-directed mutagenesis [223]. The specific activity for Met315Leu and Met446Leu was decreased by more than 76\%, while Met17Leu, Met104Leu, Met208Leu, Met214Leu, Met292Leu, and Met324Leu showed 247, $128,37,260,232$, and $241 \%$ higher activity than the wild-type enzyme, respectively. Wild-type enzyme was sensitive to chemical oxidation, but Met208Leu was stable even in the presence of $500 \mathrm{mM} \mathrm{H} \mathrm{O}_{2}$. Except for Met214Leu, which was quite sensitive to $\mathrm{H}_{2} \mathrm{O}_{2}$, the other mutants showed a profile of oxidative inactivation similar to that of the wild-type enzyme. These observations indicate that the oxidative stability of this enzyme can be improved by replacement of the critical methionine residue with leucine, but that in some cases this change may even have a negative effect on the enzyme tolerance to hydrogen peroxide. Moreover, each of the six oxidative-sensitive methionine residues in D-amino acid oxidase from Trigonopsis variabilis was changed to leucine by site-directed mutagenesis [90]. The specific activity of four mutant 
DAAOs (Met104Leu, Met226Leu, Met245Leu, and Met339Leu) was decreased by more than 96\%, while Met156Leu and Met209Leu showed about 23\% and 96\% higher activity than the wild-type enzyme, respectively. Met156Leu, Met209Leu, and Met226Leu were resistant to inactivation by $50 \mathrm{mM} \mathrm{H}_{2} \mathrm{O}_{2}$. The other three mutant DAAOs were also slightly more resistant than the wild-type enzyme to chemical oxidation.

However, in some cases, the replacement of each of the Met residues even produced a decrease in enzyme stability versus hydrogen peroxide. For example, each of the five methionine residues of recombinant leucine aminopeptidases from Bacillus stearothermophilus was replaced with leucine by site-directed mutagenesis [224]. The specific activities for Met82Leu, Met88Leu, Met254Leu, and Met382Leu were similar to those of the wild-type enzyme, whereas a reduced activity was observed in Met136Leu. As compared with the wildtype enzyme, all mutant proteins were more sensitive to the oxidant, implying that the methionine residues of this leucine aminopeptidases are important for the protection of the enzyme from oxidative inactivation.

In other cases, Cys are the target of the genetic modification. For example, ascorbate peroxidase isoforms localized in the stroma and thylakoid of the chloroplast play a key role in detoxifying hydrogen peroxide generated in photosystem I. However, once the ascorbate is depleted, the enzyme is attacked by $\mathrm{H}_{2} \mathrm{O}_{2}$ and rapidly loses its activity [225]. The wild-type enzyme had an inactivation half-time of $10 \mathrm{~s}$ in the presence of hydrogen peroxide, while the triple mutant (Cys26, Trp35, and Cys126) retained 50\% of the initial activity after $\mathrm{H}_{2} \mathrm{O}_{2}$ treatment for $3 \mathrm{~min}$. The hydrogen peroxide tolerance of this mutant was comparable to that of the hydrogen peroxide -tolerant ascorbate peroxidase isoform localized in the cytosol. In another case, the P-form of rat glutathione transferase was studied. It is inactivated by hydrogen peroxide via the formation of intra- or intersubunit disulfides [226]. Enzyme variants whose cysteine residues were independently substituted with alanine (C14A, C47A, C101A, and C169A) by site-directed mutagenesis C14A and C169A were significantly more inactivated than 
native GST-P by $1 \mathrm{mM} \mathrm{H}_{2} \mathrm{O}_{2}$, whereas C47A and, especially, C101A appeared to become insensitive to this concentration of hydrogen peroxide.

In other cases, Trp has been the target group to be replaced. Hydrogen peroxide inactivation of the superoxide dismutases from Propionibacterium shermanii, has been studied in the native and Val $73 \rightarrow$ Trp mutant enzymes [227]. The enzyme is active with either iron or manganese at the active site. The wild-type iron-containing form of this enzyme is much more resistant to treatment with $\mathrm{H}_{2} \mathrm{O}_{2}$ with respect to the other metal-specific Fe superoxide dismutase isoenzymes. After incubation with high amounts of $\mathrm{H}_{2} \mathrm{O}_{2}$ the enzyme maintains more than $40 \%$ of the initial activity. The activity of the Val $73 \rightarrow$ Trp mutant drastically decreases to less than $5 \%$ of the initial activity after incubation with hydrogen peroxide. Amino acid analysis of the $\mathrm{H}_{2} \mathrm{O}_{2}$-treated mutant enzyme evidenced the loss of the $\operatorname{Trp} 73$ residue which has been shown to play a critical role in the stabilization of the monomer fold of the enzyme. On the other hand, the manganese-containing wild-type and mutant enzymes were completely resistant toward $\mathrm{H}_{2} \mathrm{O}_{2}$ demonstrating the specific role of iron in the inactivation process. Another example of this strategy is the construction of a tryptophanless mutant of horseradish peroxidase, which was expressed in Escherichia coli. After refolding, the specific activity of the mutant enzyme was 1100-1500 U/mg (compared to $2000 \mathrm{U} / \mathrm{mg}$ for the recombinant wild-type enzyme) [228]. The effect of hydrogen peroxide pretreatment on the radiation-induced inactivation of the wild-type and mutant enzyme indirectly indicates participation of Trp-117 in electron transfer pathways through the enzyme molecule.

In other instances, Lys and Glu are the objective to be replaced by other less reactive amino acids. For example, horseradish peroxidase (HRP) is a commonly used enzyme in many biotechnological fields, and its low resistance to hydrogen peroxide is a limitation for its implementation in many instances [229]. To reach this goal, 13 single- and three double-mutants of solvent exposed, proximal lysine and glutamic acid residues were analysed. Additionally, five single- and one pentuple-consensus mutants were investigated. Most mutants displayed little or 
no alteration in $\mathrm{H}_{2} \mathrm{O}_{2}$ stability experiments; however, three variants exhibited significantly increased $\mathrm{H}_{2} \mathrm{O}_{2}$ tolerances of 25 (T110V), 18 (K232N), and 12-fold (K241F). This improved stability was attributed to an altered enzyme- $\mathrm{H}_{2} \mathrm{O}_{2}$ catalysis pathway or to removal of potentially oxidisable residues.

In another example, the truncated form of thioredoxin peroxidase from Schizosaccharomyces pombe was subject to site directed mutagenisis. The truncated enzyme was significantly more resilient against inactivation by hydrogen peroxide than the intact form [230]. Peroxidase assay of a series of recombinant C-terminal truncation mutants $(\Delta 192, \Delta 191$, $\Delta 188, \Delta 184, \Delta 176$, and $\Delta 165)$ revealed that thioredoxin peroxidase could be inactivated $(\Delta 192)$, reactivated $(\Delta 191-\Delta 176)$ and reinactivated $(\Delta 165)$ by serial truncation from $\mathrm{C}$-terminus. Characterization of a series of Lys191 point mutants manifested that the loss of affinity caused by deprivation of positive charge born in Lys191 and the loss of affinity resulted in the resistibility to hydrogen peroxide.

In other instances, the main objective was to prevent the destruction of the prostetic group of the enzyme. Hemo group of 1-cytochrome $c$ is destroyed in presence of hydrogen peroxide. Variants of the iso-1-cytochrome c were constructed by site-directed mutagenesis and were found to be more stable in the presence of hydrogen peroxide than the wild type [231]. No heme destruction was detected in a triple variant $($ Tyr67 $\rightarrow$ Phe/Asn52 $\rightarrow$ Ile/Cys102 $\rightarrow$ Thr) with the catalytic hydrogen peroxide concentration of $1 \mathrm{mM}$. The absence of a protein radical in the more resistant variant suggests that the protein radical is necessary in the heme destruction process, but presumably is not involved in the reactions leading up to protein inactivation.

\subsection{Evolved enzymes}

Directed evolution of enzymes has revealed itself as a powerful tool to improve enzyme properties. It has been used in some instance on many enzymes [232-234], but in most cases the objective was to improve enzyme activity or stability versus organic medium or 
temperature. The number of reports in which a direct effort to improve enzyme stability versus hydrogen peroxide is described is hitherto scarce.

Manganese peroxidase stability in the presence of hydrogen peroxide was increased by molecular evolution [235]. After several rounds of immobilizations, four positive mutants with nine times higher hydrogen peroxide stability than that of the wild-type were located.

A S. cerevisiae strain encoding a mutant horseradish peroxidase enzyme was submitted to random mutagenesis, recombination, and screening to identify mutants that are more active and stable to incubation in hydrogen peroxide at $50{ }^{\circ} \mathrm{C}$ [236]. A single mutation (N175S) in the HRP active site was found to improve thermal stability. The variant is also more stable in the presence of $\mathrm{H}_{2} \mathrm{O}_{2}$, SDS, salts ( $\mathrm{NaCl}$ and urea), and at different $\mathrm{pH}$ values.

The heme peroxidase from Coprinus cinereus was subjected to multiple rounds of directed evolution in an effort to produce a mutant stable in laundry detergent conditions: pH 10.5 at $50^{\circ} \mathrm{C}$ and 5-10 $\mathrm{mM}$ peroxide concentration [237]. Manually combining mutations from the site-directed and random approaches led to a mutant with 110 times the thermal stability and 2.8 times the oxidative stability of the wild-type enzyme. In the final two rounds, mutants were randomly recombined by using the efficient yeast homologous recombination system to shuffle point mutations among a large number of parents. This in vivo shuffling led to the most dramatic improvements in oxidative stability, yielding a mutant with 174 times the thermal stability and 100 times the oxidative stability of wild-type enzyme [237].

\section{Physico-chemical modification of enzymes to increase their stability in the presence of hydrogen peroxide}

\subsection{Immobilization}

Immobilization is a very powerful tool that may bring forth substantial improvements in enzyme performance, by increasing enzyme rigidity, preventing multimeric enzyme dissociation or generating suitable enzyme nano-environments [128, 162, 238, 239]. 
Inactivation of enzymes due to the action of hydrogen peroxide may also be prevented, or at least its effects minimized, by immobilization. This protective effect may be achieved via two different pathways:

1.- removing the cause for inactivation: e,g,, decreasing the concentration of hydrogen peroxide in the environment of the residues susceptible of being modified by hydrogen peroxide(Figure 4), or reducing the exposition of a critical group by keeping it inside the enzyme core (Figure 5).

2.- decreasing the effect of the chemical modification: if the chemical modification facilitates undesired conformational changes in the enzyme, an intense multipoint covalent attachment may reduce this negative effect. (Figure 6)

Now, we will show some examples where enzyme stability in the presence of hydrogen peroxide is improved by different reasons.

\subsubsection{Enzyme stabilization versus hydrogen peroxide by decreasing the} exposition of the susceptible groups to lower peroxide concentration

It is possible to find various examples where enzymes have been stabilized versus hydrogen peroxide by the promotion of a partition of hydrogen peroxide, usually generating a hydrophobic environment around the enzyme by using hydrophobic supports (Figure 4).

Many of these studies involve lipases. Lipases are used in chemo-enzymatic epoxidations of diverse substances (Table 1) [10, 11, 240-243]. In this reaction, hydrogen peroxide (or some derivative) is one of the reaction substrate, and it has been shown that the catalytic residue of the enzyme is involved [244]. This reaction in particular has been recently reviewed [245]. The main bottleneck for the chemo-enzymatic epoxidation catalyzed by lipases has been found to be enzyme inactivation by hydrogen peroxide [246]. Lipase B from Pseudozyma (formerly Candida) antarctica (CALB) is one of the most studied enzymes, due to its moderate stability in the presence of this reagent. The effect on the primary, secondary, 
tertiary and quaternary structure of CALB upon exposure to hydrogen peroxide has been investigated [64, 247]. The presence of protein aggregates whose concentration increased with increasing incubation time has been reported during this process. Furthermore, it has been shown that elevated concentration of $\mathrm{H}_{2} \mathrm{O}_{2}$ result in partial fragmentation of the protein. Oxidation of methionine, tryptophan and cystine residues has also been found. The histidine active site was not observed in the oxidized form. However, drastic changes in the enzyme structure could be found [64].

Immobilization of CALB on smectite group nanoclays (Laponite, SWy-2 and Kunipia), as well as on their organically modified derivatives, has permitted to improve its stability in the presence of hydrogen peroxide [248]. The immobilized lipase on such modified nanoclays can be effectively applied for the indirect epoxidation of $\alpha$-pinene using hydrogen peroxide as substrate. The amount of $\alpha$-pinene epoxide produced in a single-step biocatalytic process is up to 3-fold higher than that of free enzyme or enzyme immobilized in non-modified clays. Moreover, lipase immobilized on modified clays retains up to $90 \%$ of its initial activity after $48 \mathrm{~h}$ of incubation in the presence of oxidant, and up to $60 \%$ after four reaction cycles, while other forms of the enzyme retain less than $10 \%$.

Recently, it has been shown how the immobilization of CALB on a hydrophobic support, decaoctyl-Sepabeads, permitted to greatly improve the enzyme stability in the presence of hydrogen peroxide, even using high concentrations (10 M) of this reagent the enzyme exhibited over 50\% activity after one week [249]. Native PAGE of the immobilized enzyme after hydrogen peroxide incubation showed no changes in mobility, while CALB from Novozym 435 showed clear changes. This was explained by the hydrophobicity of the enzyme environment that seems to be enough to protect the enzyme residues involved in the immobilization from enzyme modification. The use of an even more hydrophobic support permitted a further increase in CALB stability under high concentrations of hydrogen peroxide [250]. Borohydride reduction of the hydrogen peroxide inactivated enzyme permitted to recover 
a large percentage of the lost activity, and this enzyme retains a thermo-stability close to that of the native enzyme [249].

In some instances, the stabilization may be achieved just by hindering the access of the hydrogen peroxide to the key group, immobilizing the enzyme in a support having a large surface area and orienting this group towards this surface (Figure 7). This has permitted to stabilize the enzyme D-amino acid oxidase from Trigonopsis variabilis even in the presence of hydrogen peroxide [251]. The heme enzymes horseradish peroxidase and metmyoglobin when reacted with hydrogen peroxide exhibited peroxidase activity [252]. Hydrogen peroxide oxidized the heme iron to ferryl state and produced protein radicals which inactivated and damaged the heme enzymes. The enzymes were encapsulated with sol-gels to protect them from peroxidase activity.

\subsubsection{Improved rigidity of the enzyme}

When the modification of hydrogen peroxide did not affect directly a catalytically relevant residue, it may be considered that the modification mainly affects enzyme stability, and thus the modified enzyme may have a certain tendency to acquire a wrong conformation Figure . In other cases, the sensitive group may be inside the core of the protein and may only become exposed to the action of hydrogen peroxide by conformational changes of the protein Figure. Thus, in both cases, if the enzyme is rigidified, some stabilization should be expected when the enzyme is exposed to the presence of hydrogen peroxide.

Many examples which couple enzyme thermo-stabilization to stabilization use the very interesting enzyme D-amino acid oxidase as example.

D-amino acid oxidase from Rhodosporidium toruloides and $\mathrm{Fe}_{3} \mathrm{O}_{4}$ magnetic nanoparticles were encapsulated simultaneously within biomimetic silica, using polyallylamine as mediator [253]. Under these conditions, the temperature at which $50 \%$ of the initial activity was retained after $1 \mathrm{~h}$ of incubation was increased from $44.3^{\circ} \mathrm{C}$ to $57.7^{\circ} \mathrm{C}$. In the presence of 50 
mM hydrogen peroxide, encapsulated RtDAO had approximately 2-fold increase in resistance to hydrogen peroxide. Glutyaraldehyde immobilization on magnetic nanoparticles of the same enzyme also coupled thermal stabilization (Tm was increased from $45{ }^{\circ} \mathrm{C}$ to $55^{\circ} \mathrm{C}$ ) with stabilization in the presence of $20 \mathrm{mM} \mathrm{H}_{2} \mathrm{O}_{2}$, (the immobilized form retained $93 \%$ of its activity after $5 \mathrm{~h}$ while the free form was completely inactivated after $3.5 \mathrm{~h}$ ) [254]. Multipoint covalently immobilized D-amino acid oxidase (DAAO) from Rhodotorula gracilis on glyoxyl-agarose is 11-fold more stable than the native enzyme against the deleterious effect of hydrogen peroxide, with an improved thermostabillity as an added benefit [251, 255]. However, D-amino acid oxidase from Trigonopsis variabilis was not stabilized by rigidification versus hydrogen peroxide although an improved thermostability was detected.

Glucose oxidase is another habitual example. Glucose oxidase adsorbed on aminated cationic supports and subsequent treatment with glutaraldehyde permitted to greatly improve its thermostability, stability both in organic media and in the presence of hydrogen peroxide [256].

Other popular enzymes are horseradish peroxidase and soybean peroxidase: Both enzymes were covalently immobilized onto aldehyde glass through their amine groups, and a clear protective effect of the immobilization against the enzyme inactivation by hydrogen peroxide was found [257, 258].

It has also been found that erythrocyte $\mathrm{Cu}, \mathrm{Zn}$-superoxide dismutase trapped in a hydrogel of carboxymethylcellulose (CMC) with 50 and 90\% cross-linking was more resistant to oxygen peroxide inactivation than the native enzyme [259]. This reduced the amount of time necessary for wound healing when the trapped enzyme was applied in injuries.

Finally a nice example is the immobilization of a manganese peroxidase that was evolved to improve the resistance towards hydrogen peroxide (see point 6.2) [235]. A mutant enzyme immobilized on a mesoporous material showed a stabilization of 5.5 folds compared to the evolved enzyme (that was 9 fold more stable than wild type MnP). However, the stability of the immobilized wild type $\mathrm{MnP}$ did not show a significant improvement compared to the 
immobilized mutant MnP. This suggests some kind of synergetic effect between the factors improving enzyme stability before and after immobilization, even though evolution was not designed to finally use the enzyme in its immobilized form [260].

\subsection{Chemical modification}

Chemical modification of enzymes has proven to be a very powerful tool to improve enzyme properties [261]. Although currently the competition with genetic modification has decreased the research in this area, its suitability to solve some enzyme limitations still has a high interest, In many examples, enzymes working with hydrogen peroxide have been the target of the study [262], although stabilization versus hydrogen peroxide has not been frequently the main goal of the research.

The highly reactive hydroxyl radical $(\cdot \mathrm{OH})$ is generated during the reaction of $\mathrm{Cu}, \mathrm{Zn}$ superoxide dismutase with $\mathrm{H}_{2} \mathrm{O}_{2}$, its own enzymatic reaction product. During inactivation of Cu,Zn-enzyme with $\mathrm{H}_{2} \mathrm{O}_{2}$, $\mathrm{Cu}^{2+}$ liberated from the SOD catalyzes the formation of $\cdot \mathrm{OH}$ from $\mathrm{H}_{2} \mathrm{O}_{2}$. The enzyme was modified with different polymers. Modification with poly(styrene-comaleic acid butyrate) and poly(ethylene glycol) did not improve enzyme stability, but the other polymers did. The residual activity of divinylether maleic acid/anhydride copolymer (pyran copolymer)-conjugated SOD was $87 \%$ of the initial activity after incubation with $0.1 \mathrm{mM}$ $\mathrm{H}_{2} \mathrm{O}_{2}$ for $2 \mathrm{~h}$, whereas that of native SOD was 49\% [263]. Pyran copolymer-superoxide dismutase presented an even higher effect on enzyme stabilization. It was attributed by the capture of loosely bound $\mathrm{Cu}^{2+}$ during the reaction of the enzyme with $\mathrm{H}_{2} \mathrm{O}_{2}$ by the polymer, thus resulting in suppression of $\cdot \mathrm{OH}$-mediated inactivation of SOD (Figure 8). Later, superoxide dismutase resistance to inactivation by hydrogen peroxide has been greatly improved by glycosidation with carboxymethylchitin. It was explained again by the chelating ability of the

polymer, which could bind the $\mathrm{Cu}^{2+}$ released from the protein structure after oxidation [264]. Through this chelating mechanism, the further occurrence of Fenton-type reactions could be 
avoided, preserving the active enzyme molecules from radical oxidation with highly toxic substances. In another paper, a catalase was chemically glycosilated with cyclodextrin- branched carboxymethylcellulose and them associated with superoxide dismutase modified with 1adamantane carboxylic acid [265]. Following this strategy, superooxide dismutase was remarkably resistant to inactivation by $\mathrm{H}_{2} \mathrm{O}_{2}$ and its anti-inflammatory activity was 4.5 -fold increased after supramolecular association with the modified catalase form.

In a similar research effort, catalase, superoxide dismutase and catalase-superoxide dismutase conjugates with aldehyde dextrans have been prepared in aqueous media and surfactant microemulsion [266]. The conjugation of catalase with aldehyde dextrans and SOD in microemulsions enhances the stability of both enzymes.

The interest in the chemical modification of proteins may be reinforced if coupled to immobilization, due to the inherent advantages of solid phase modification and the aforementioned improvement of enzyme features due to immobilization [238, 267]. One example of this coupled use of two apparently unrelated tools may be found in D-amino acid oxidase from Trigonopsis variabilis has been also stabilized versus hydrogen peroxide [251], by coating the surface of the immobilized enzyme with dextran or even a hydrophobic derivative of this compound (Figure 9). Although the modification presented a negative effect on enzyme thermostability, the stability of the enzyme in the presence of hydrogen peroxide increased.

\section{Conclusions}

Hydrogen peroxide is a useful oxidant [1-3] in many different biocatalytic reactions [8, 49, 51, 52, 205]. However, it is also able to seriously damage the chemical structure of the proteins, inactivating enzymes. The problem becomes even more serious if some metals are present in the medium.

Fortunately, as it has been presented in this review, the researcher may act at different levels to avoid enzyme inactivation. Inactivation may be promoted by a direct destruction of the 
active center, or by de-stabilization of the enzyme. Solutions involve both increase in enzyme rigidity and decrease in hydrogen peroxide and metal accessibility to the enzyme. Destruction of hydrogen peroxide using inorganic catalysts or catalases is the simplest solution if the hydrogen peroxide is a by-product. To keep the hydrogen peroxide under a critical concentration may be a solution if it is a substrate. Some additives may prevent enzyme inactivation, acting as antioxidant in some cases but in others just removing metals that may accelerate enzyme inactivation from the solution (metals that may be part of the enzyme structure). Genetic tools have also shown a great potential to increase enzyme stability versus hydrogen peroxide, by changing sensitive groups or by increasing enzyme rigidity. In a similar way, chemical modification and immobilization may be very potent tools to increase enzyme rigidity, or to generate hydrophobic environments that produce a partition of the hydrogen peroxide way from the enzyme surroundings.

Stability of enzymes versus temperature or organic solvents has been tackled using very different tools in a combined way (e.g. coupled use of immobilization with site directed mutagenesis, chemical modification or use of enzymes from thermophiles [238, 260, 267]. Very likely, a similarly integrated strategy, combining all the tools presented above, together to selection of enzymes more naturally resistant to hydrogen peroxide, may greatly increase the future interest of this liaison between hydrogen peroxide, and biocatalysis or biosensors design.

\section{Acknowledgements}

This work has been supported by grant CTQ2009-07568 from Spanish Ministerio de Ciencia e Innovación. A. Berenguer-Murcia thanks the Spanish Ministerio de Ciencia e Innovación for a Ramon y Cajal fellowship (RyC-2009-03813). 


\section{References}

[1] De Faveri, G.; Ilyashenko, G.; Watkinson, M. Recent advances in catalytic asymmetric epoxidation using the environmentally benign oxidant hydrogen peroxide and its derivatives. Chem. Soc. Rev., 2011, 40, 1722-1760.

[2] Podgoršek, A.; Zupan, M.; Iskra, J. Oxidative halogenation with "green" oxidants: Oxygen and hydrogen peroxide. Angew. Chem., Int. Ed., 2009, 48, 8424-8450.

[3] Schrader, S.; Dehmlow, E.V. Hydrogen peroxide and air as inexpensive oxidants in phase-transfer catalysis. A review. Org. Prep. Proced. Int., 2000, 32, 123-152.

[4] Smith, G.V.; Notheisz, F. In Heterogeneous Catalysis in Organic Chemistry. Smith, G.V.; Notheisz, F., Eds.; Academic Press: San Diego, 1999, pp 229-246.

[5] Saliu, F.; Tolppa, E.L.; Zoia, L.; Orlandi, M. Horseradish peroxidase catalyzed oxidative cross-coupling reactions: The synthesis of 'unnatural' dihydrobenzofuran lignans. Tetrahedron Lett., 2011, 52, 3856-3860.

[6] Moussouni, S.; Detsi, A.; Majdalani, M.; Makris, D.P.; Kefalas, P. Crude peroxidase from onion solid waste as a tool for organic synthesis. Part I: Cyclization of 2',3,4,4',6'-pentahydroxy-chalcone into aureusidin. Tetrahedron Lett., 2010, 51, 4076-4078.

[7] Moussouni, S.; Saru, M.L.; Ioannou, E.; Mansour, M.; Detsi, A.; Roussis, V.; Kefalas, P. Crude peroxidase from onion solid waste as a tool for organic synthesis. Part II: Oxidative dimerization-cyclization of methyl p-coumarate, methyl caffeate and methyl ferulate. Tetrahedron Lett., 2011, 52, 1165-1168.

[8] Van Deurzen, M.P.J.; Van Rantwijk, F.; Sheldon, R.A. Selective oxidations catalyzed by peroxidases. Tetrahedron, 1997, 53, $13183-13220$.

[9] Kumar, A.; Sharma, S.; Maurya, R.A. Bienzymatic synthesis of benzothia/(oxa)zoles in aqueous medium. Tetrahedron Lett., 2010, 51, 62246226.

[10] Da Silva, J.M.R.; Nascimento, M.D.G. Chemoenzymatic epoxidation of citronellol catalyzed by lipases. Process Biochem., 2012, 47, 517522.

[11] Silva, W.S.D.; Lapis, A.A.M.; Suarez, P.A.Z.; Neto, B.A.D. Enzyme-mediated epoxidation of methyl oleate supported by imidazoliumbased ionic liquids. J. Mol. Catal. B: Enzym., 2011, 68, 98-103.

[12] Dembitsky, V.M. Oxidation, epoxidation and sulfoxidation reactions catalysed by haloperoxidases. Tetrahedron, 2003, 59, 4701-4720.

[13] Wu, J.; Liu, C.; Jiang, Y.; Hu, M.; Li, S.; Zhai, Q. Synthesis of chiral epichlorohydrin by chloroperoxidase-catalyzed epoxidation of 3chloropropene in the presence of an ionic liquid as co-solvent. Catal. Commun., 2010, 11, 727-731.

[14] Lin, H.; Liu, J.Y.; Wang, H.B.; Ahmed, A.A.Q.; Wu, Z.L. Biocatalysis as an alternative for the production of chiral epoxides: A comparative review. J. Mol. Catal. B: Enzym., 2011, 72, 77-89.

[15] Hofrichter, M.; Ullrich, R. Heme-thiolate haloperoxidases: versatile biocatalysts with biotechnological and environmental significance. Appl. Microbiol. Biotechnol., 2006, 71, 276-288.

[16] Ullrich, R.; Dolge, C.; Kluge, M.; Hofrichter, M. Pyridine as novel substrate for regioselective oxygenation with aromatic peroxygenase from Agrocybe aegerita. FEBS Lett., 2008, 582, 4100-4106.

[17] Kluge, M.; Ullrich, R.; Dolge, C.; Scheibner, K.; Hofrichter, M. Hydroxylation of naphthalene by aromatic peroxygenase from Agrocybe aegerita proceeds via oxygen transfer from $\mathrm{H}_{2} \mathrm{O}_{2}$ and intermediary epoxidation. Appl. Microbiol. Biotechnol., 2009, 81, 1071-1076.

[18] Kroutil, W.; Mang, H.; Edegger, K.; Faber, K. Biocatalytic oxidation of primary and secondary alcohols. Adv. Synth. Catal., 2004, 346, 125-142.

[19] Holland, H.L.; Brown, F.M.; Johnson, D.V.; Kerridge, A.; Mayne, B.; Turner, C.D.; Van Vliet, A.J. Biocatalytic oxidation of Salkylcysteine derivatives by chloroperoxidase and Beauveria species. Journal of Molecular Catalysis - B Enzymatic, 2002, 17, 249-256. 
[20] Franssen, M.C.R.; Van Der Plas, H.C. The chlorination of barbituric acid and some of its derivatives by chloroperoxidase. Bioorg. Chem., 1987, $15,59-70$.

[21] Franssen, M.C.R.; Van Boven, H.G.; Van Der Plas, H.C. Enzymatic halogenation of pyrazoles and pyridine derivatives. J. Heterocycl. Chem., 1987, 24, 1313-1316.

[22] Sala, A.; Nicolis, S.; Roncone, R.; Casella, L.; Monzani, E. Peroxidase catalyzed nitration of tryptophan derivatives: Mechanism, products and comparison with chemical nitrating agents. Eur. J. Biochem., 2004, 271, 2841-2852.

[23] Siebum, A.; van Wijk, A.; Schoevaart, R.; Kieboom, T. Galactose oxidase and alcohol oxidase: Scope and limitations for the enzymatic synthesis of aldehydes. J. Mol. Catal. B: Enzym., 2006, 41, 141-145.

[24] Turner, N.J. Enantioselective Oxidation of C-O and C-N bonds using oxidases. Chem. Rev., 2011, 111, 4073-4087.

[25] Ferreira, P.; Hernández-Ortega, A.; Herguedas, B.; Rencoret, J.; Gutiérrez, A.; Martínez, M.J.; Jiménez-Barbero, J.; Medina, M.; Martínez, Á.T. Kinetic and chemical characterization of aldehyde oxidation by fungal aryl-alcohol oxidase. Biochem. J., 2010, 425, 585-593.

[26] Wu, P.; He, Y.; Wang, H.F.; Yan, X.P. Conjugation of glucose oxidase onto Mn-doped Zns quantum dots for phosphorescent sensing of glucose in biological fluids. Anal. Chem., 2010, 82, 1427-1433.

[27] Zhou, K.; Zhu, Y.; Yang, X.; Li, C. Electrocatalytic oxidation of glucose by the glucose oxidase immobilized in graphene-au-nafion biocomposite. Electroanalysis, 2010, 22, 259-264.

[28] Wang, K.; Liu, Q.; Guan, Q.M.; Wu, J.; Li, H.N.; Yan, J.J. Enhanced direct electrochemistry of glucose oxidase and biosensing for glucose via synergy effect of graphene and CdS nanocrystals. Biosens. Bioelectron., 2011, 26, 2252-2257.

[29] Franke, D.; Machajewski, T.; Hsu, C.-C.; Wong, C.-H. One-Pot Synthesis of l-Fructose Using Coupled Multienzyme Systems Based on Rhamnulose-1-phosphate Aldolase. The Journal of Organic Chemistry, 2003, 68, 6828-6831.

[30] Fuchs, M.; Schober, M.; Pfeffer, J.; Kroutil, W.; Birner-Gruenberger, R.; Faber, K. Homoallylic alcohols via a chemo-enzymatic one-pot oxidation-allylation cascade. Adv. Synth. Catal., 2011, 353, 2354-2358.

[31] Gao, C.; Zhang, W.; Ma, C.; Liu, P.; Xu, P. Kinetic resolution of 2-hydroxybutanoate racemic mixtures by NAD-independent l-lactate dehydrogenase. Bioresour. Technol., 2011, 102, 4595-4599.

[32] Das, S.; Glenn Iv, J.H.; Subramanian, M. Enantioselective oxidation of 2-hydroxy carboxylic acids by glycolate oxidase and catalase coexpressed in methylotrophic Pichia pastoris. Biotechnol. Prog., 2010, 26, 607-615.

[33] Pollegioni, L.; Piubelli, L.; Molla, G. Cholesterol oxidase: Biotechnological applications. FEBS J., 2009, 276, 6857-6870.

[34] Saxena, U.; Chakraborty, M.; Goswami, P. Covalent immobilization of cholesterol oxidase on self-assembled gold nanoparticles for highly sensitive amperometric detection of cholesterol in real samples. Biosens. Bioelectron., 2011, 26, 3037-3043.

[35] Manjunatha, R.; Nagaraju, D.H.; Suresh, G.S.; Melo, J.S.; D'Souza, S.F.; Venkatesha, T.V. Direct electrochemistry of cholesterol oxidase on MWCNTs. J. Electroanal. Chem., 2011, 651, 24-29.

[36] Schrittwieser, J.H.; Sattler, J.; Resch, V.; Mutti, F.G.; Kroutil, W. Recent biocatalytic oxidation-reduction cascades. Curr. Opin. Chem. Biol., 2011, 15, 249-256.

[37] Pollegioni, L.; Molla, G. New biotech applications from evolved D-amino acid oxidases. Trends Biotechnol., 2011, $29,276-283$.

[38] Buto, S.; Pollegioni, L.; D'Angiuro, L.; Pilone, M.S. Evaluation of D-amino acid oxidase from Rhodotorula gracilis for the production of $\alpha$ keto acids: A reactor system. Biotechnol. Bioeng., 1994, 44, 1288-1294.

[39] Savile, C.K.; Janey, J.M.; Mundorff, E.C.; Moore, J.C.; Tam, S.; Jarvis, W.R.; Colbeck, J.C.; Krebber, A.; Fleitz, F.J.; Brands, J.; Devine, P.N.; Huisman, G.W.; Hughes, G.J. Biocatalytic asymmetric synthesis of chiral amines from ketones applied to sitagliptin manufacture. Science, 2010, 329, 305-309. 
[40] Köhler, V.; Bailey, K.R.; Znabet, A.; Raftery, J.; Helliwell, M.; Turner, N.J. Enantioselective biocatalytic oxidative desymmetrization of substituted pyrrolidines. Angew. Chem., Int. Ed., 2010, 49, 2182-2184.

[41] Shamsipur, M.; Asgari, M.; Maragheh, M.G.; Moosavi-Movahedi, A.A. A novel impedimetric nanobiosensor for low level determination of hydrogen peroxide based on biocatalysis of catalase. Bioelectrochemistry, 2012, 83, 31-37.

[42] Itoh, T.; Ishii, R.; Matsuura, S.i.; Hamakawa, S.; Hanaoka, T.; Tsunoda, T.; Mizuguchi, J.; Mizukami, F. Catalase encapsulated in mesoporous silica and its performance. Biochem. Eng. J., 2009, 44, 167-173.

[43] Karmali, A.; Coelho, J. Bioconversion of d-glucose into d-glucosone by immobilized glucose 2-oxidase from Coriolus versicolor at moderate pressures. Process Biochem., 2011, 46, 168-173.

[44] Schrittwieser, J.H.; Resch, V.; Sattler, J.H.; Lienhart, W.D.; Durchschein, K.; Winkler, A.; Gruber, K.; MacHeroux, P.; Kroutil, W. Biocatalytic enantioselective oxidative C-C coupling by aerobic C-H activation. Angew. Chem., Int. Ed., 2011, 50, 1068-1071.

[45] Wang, L.; Wei, L.; Chen, Y.; Jiang, R. Specific and reversible immobilization of NADH oxidase on functionalized carbon nanotubes. J. Biotechnol., 2010, 150, 57-63.

[46] Jiang, R.; Bommarius, A.S. Hydrogen peroxide-producing NADH oxidase (nox-1) from Lactococcus lactis. Tetrahedron Asymmetry, 2004, 15, 2939-2944.

[47] Twala, B.V.; Sewell, B.T.; Jordaan, J. Immobilisation and characterisation of biocatalytic co-factor recycling enzymes, glucose dehydrogenase and NADH oxidase, on aldehyde functional ReSyn ${ }^{\mathrm{TM}}$ polymer microspheres. Enzyme Microb. Technol., 2012, 50, 331-336.

[48] Wu, X.; Kobori, H.; Orita, I.; Zhang, C.; Imanaka, T.; Xing, X.H.; Fukui, T. Application of a novel thermostable NAD(P)H oxidase from hyperthermophilic archaeon for the regeneration of both NAD + and NADP +. Biotechnol. Bioeng., 2012, 109, 53-62.

[49] Deisseroth, A.; Dounce, A.L. Catalase: Physical and chemical properties, mechanism of catalysis, and physiological role. Physiol. Rev., 1970, 50, 319-375.

[50] Nicholls, P.; Fita, I.; Loewen, P.C. Enzymology and structure of catalases. Adv. Inorg. Chem., 2000, 51, 51-106.

[51] Wilson, R.; Turner, A.P.F. Glucose oxidase: An ideal enzyme. Biosens. Bioelectron., 1992, 7, 165-185.

[52] Wu, H.; Wang, J.; Kang, X.; Wang, C.; Wang, D.; Liu, J.; Aksay, I.A.; Lin, Y. Glucose biosensor based on immobilization of glucose oxidase in platinum nanoparticles/graphene/chitosan nanocomposite film. Talanta, 2009, 80, 403-406.

[53] Choi, O.; Kim, B.C.; An, J.H.; Min, K.; Kim, Y.H.; Um, Y.; Oh, M.K.; Sang, B.I. A biosensor based on the self-entrapment of glucose oxidase within biomimetic silica nanoparticles induced by a fusion enzyme. Enzyme Microb. Technol., 2011, 49, 441-445.

[54] Giorgio, M.; Trinei, M.; Migliaccio, E.; Pelicci, P.G. Hydrogen peroxide: A metabolic by-product or a common mediator of ageing signals? Nat. Rev. Mol. Cell Biol., 2007, 8, 722-728.

[55] Rojkind, M.; Domínguez-Rosales, J.A.; Nieto, N.; Greenwel, P. Role of hydrogen peroxide and oxidative stress in healing responses. Cell. Mol. Life Sci., 2002, 59, 1872-1891.

[56] Grey, C.E.; Hedström, M.; Adlercreutz, P. A mass spectrometric investigation of native and oxidatively inactivated chloroperoxidase. ChemBioChem, 2007, 8, 1054-1062.

[57] Stadtman, E.R.; Levine, R.L. Free radical-mediated oxidation of free amino acids and amino acid residues in proteins. Amino Acids, 2003, 25, 207-218.

[58] Greenfield, P.F.; Kittrell, J.R.; Laurence, R.L. Inactivation of immobilized glucose oxidase by hydrogen peroxide. Anal. Biochem., 1975, $65,109-124$

[59] Obregón, V.; Mata, I.d.l.; Ramón, F.; Acebal, C.; Castillón, M.P., 1998; Vol. 15, pp 89-94.

[60] Brodelius, P.; Nilsson, K.; Mosbach, K. Production of $\alpha$-keto acids Part I. Immobilized cells of Trigonopsis variabilis containing D-amino acid oxidase. Appl. Biochem. Biotechnol., 1981, 6, 293-307. 
[61] Pollegioni, L.; Molla, G.; Sacchi, S.; Rosini, E.; Verga, R.; Pilone, M.S. Properties and applications of microbial D-amino acid oxidases: Current state and perspectives. Appl. Microbiol. Biotechnol., 2008, 78, 1-16.

[62] Volpato, G.; Rodrigues, R.C.; Fernandez-Lafuente, R. Use of enzymes in the production of semi-synthetic penicillins and cephalosporins: Drawbacks and perspectives. Curr. Med. Chem., 2010, 17, 3855-3873.

[63] Bjorkling, F.; Frykman, H.; Godtfredsen, S.E.; Kirk, O. Lipase catalyzed synthesis of peroxycarboxylic acids and lipase mediated oxidations. Tetrahedron, 1992, 48, 4587-4592.

[64] Törnvall, U.; Hedström, M.; Schillén, K.; Hatti-Kaul, R. Structural, functional and chemical changes in Pseudozyma antarctica lipase B on exposure to hydrogen peroxide. Biochimie, 2010, 92, 1867-1875.

[65] Hagström, A.E.V.; Törnvall, U.; Nordblad, M.; Hatti-Kaul, R.; Woodley, J.M. Chemo-enzymatic epoxidation-process options for improving biocatalytic productivity. Biotechnol. Prog., 2011, 27, 67-76.

[66] Cerami, A.; Vlassara, H.; Brownlee, M. Glucose and aging. Sci. Am., 1987, 256, 90-96.

[67] Lee, A.T.; Cerami, A. In Handbook of the biology of aging, 3rd ed. Schneider, E.L.; Rowe, J.W., Eds.; Academic Press: New York, 1990, pp 116-130.

[68] Wolff, S.P.; Garner, A.; Dean, R.T. Free radicals, lipids and protein degradation. Trends Biochem. Sci., 1986, 11, 27-31.

[69] Grandhee, S.K.; Monnier, V.M. Mechanism of formation of the maillard protein cross-link pentosidine: Glucose, fructose, and ascorbate as pentosidine precursors. J. Biol. Chem., 1991, 266, 11649-11653.

[70] Smith, M.A.; Sayre, L.M.; Anderson, V.E.; Harris, P.L.R.; Beal, M.F.; Kowall, N.; Perry, G. Cytochemical Demonstration of Oxidative Damage in Alzheimer Disease by Immunochemical Enhancement of the Carbonyl Reaction with 2,4-Dinitrophenylhydrazine. J. Histochem. Cytochem., 1998, 46, 731-735.

[71] Robinson, C.E.; Keshavarzian, A.; Pasco, D.S.; Frommel, T.O.; Winship, D.H.; Holmes, E.W. Determination of protein carbonyl groups by immunoblotting. Anal. Biochem., 1999, 266, 48-57.

[72] Maskos, Z.; Rush, J.D.; Koppenol, W.H. The hydroxylation of phenylalanine and tyrosine: A comparison with salicylate and tryptophan. Arch. Biochem. Biophys., 1992, 296, 521-529.

[73] Wells-Knecht, M.C.; Huggins, T.G.; Dyer, D.G.; Thorpe, S.R.; Baynes, J.W. Oxidized amino acids in lens protein with age. Measurement of o-tyrosine and dityrosine in the aging human lens. J. Biol. Chem., 1993, 268, 12348-12352.

[74] Balakrishnan, I.; Reddy, M.P. Mechanism of reaction of hydroxyl radicals with benzene in the $\gamma$ radiolysis of the aerated aqueous benzene system. J. Phys. Chem., 1970, 74, 850-855.

[75] Davies, K.J.; Delsignore, M.E.; Lin, S.W. Protein damage and degradation by oxygen radicals. II. Modification of amino acids. J. Biol. Chem., 1987, 262, 9902-9907.

[76] Dean, R.T.; Gieseg, S.; Davies, M.J. Reactive species and their accumulation on radical-damaged proteins. Trends Biochem. Sci., 1993, 18, 437-441.

[77] Giulivi, C.; Davies, K.J.A. Dityrosine and tyrosine oxidation products are endogenous markers for the selective proteolysis of oxidatively modified red blood cell hemoglobin by (the 19 S) proteasome. J. Biol. Chem., 1993, 268, 8752-8759.

[78] Huggins, T.G.; Wells-Knecht, M.C.; Detorie, N.A.; Baynes, J.W.; Thorpe, S.R. Formation of o-tyrosine and dityrosine in proteins during radiolytic and metal-catalyzed oxidation. J. Biol. Chem., 1993, 268, 12341-12347.

[79] Heinecke, J.W.; Li, W.; Daehnke Iii, H.L.; Goldstein, J.A. Dityrosine, a specific marker of oxidation, is synthesized by the myeloperoxidase-hydrogen peroxide system of human neutrophils and macrophages. J. Biol. Chem., 1993, 268 , $4069-4077$.

[80] Armstrong, R.C.; Swallow, A.J. Pulse- and gamma-radiolysis of aqueous solutions of tryptophan. Radiat. Res., 1969, 40, 563-579. 
[81] Winchester, R.V.; Lynn, K.R. X- and gamma-radiolysis of some tryptophan dipeptides. Int. J. Radiat. Biol. Relat. Stud. Phys. Chem. Med., 1970, $17,541-548$

[82] Kikugawa, K.; Kato, T.; Okamoto, Y. Damage of amino acids and proteins induced by nitrogen dioxide, a free radical toxin, in air. Free Radic. Biol. Med., 1994, 16, 373-382.

[83] Levine, R.L.; Mosoni, L.; Berlett, B.S.; Stadtman, E.R. Methionine residues as endogenous antioxidants in proteins. Proc. Natl. Acad. Sci. U. S. A., 1996, 93, 15036-15040.

[84] Levine, R.L.; Moskovitz, J.; Stadtman, E.R. Oxidation of methionine in proteins: Roles in antioxidant defense and cellular regulation. IUBMB Life, 2000, 50, 301-307.

[85] Vogt, W. Oxidation of methionyl residues in proteins: Tools, targets, and reversal. Free Radic. Biol. Med., 1995, 18, 93-105.

[86] Reddy, V.Y.; Desrochers, P.E.; Pizzo, S.V.; Gonias, S.L.; Sahakian, J.A.; Levine, R.L.; Weise, S.J. Oxidative dissociation of human $\alpha$ 2macroglobulin tetramers into dysfunctional dimers. J. Biol. Chem., 1994, 269, 4683-4691.

[87] Ciorba, M.A.; Heinemann, S.H.; Weissbach, H.; Brot, N.; Hoshi, T. Modulation of potassium channel function by methionine oxidation and reduction. Proc. Natl. Acad. Sci. U. S. A., 1997, 94, 9932-9937.

[88] Taggart, C.; Cervantes-Laurean, D.; Kim, G.; McElvaney, N.G.; Wehr, N.; Moss, J.; Levine, R.L. Oxidation of either methionine 351 or methionine 358 in $\alpha$ 1-antitrypsin causes loss of anti-neutrophil elastase activity. J. Biol. Chem., 2000, 275, $27258-27265$.

[89] Nidetzky, B. Stability and stabilization of D-amino acid oxidase from the yeast Trigonopsis variabilis. Biochem. Soc. Trans., 2007, 35, 1588-1592.

[90] Ju, S.S.; Lin, L.L.; Chien, H.R.; Hsu, W.H. Substitution of the critical methionine residues in Trigonopsis variabilis D-amino acid oxidase with leucine enhances its resistance to hydrogen peroxide. FEMS Microbiol. Lett., 2000, 186, 215-219.

[91] Li, C.; Sun, S.; Park, D.; Jeong, H.O.; Chung, H.Y.; Liu, X.X.; Zhou, H.M. Hydrogen peroxide targets the cysteine at the active site and irreversibly inactivates creatine kinase. Int. J. Biol. Macromol., 2011, 49, 910-916.

[92] Zhou, H.; Singh, H.; Parsons, Z.D.; Lewis, S.M.; Bhattacharya, S.; Seiner, D.R.; Labutti, J.N.; Reilly, T.J.; Tanner, J.J.; Gates, K.S. The biological buffer bicarbonate/ $\mathrm{CO}_{2}$ potentiates $\mathrm{H}_{2} \mathrm{O}_{2}$-mediated inactivation of protein tyrosine phosphatases. J. Am. Chem. Soc., 2011, 133, 15803-15805.

[93] Rosas-Rodríguez, J.A.; Valenzuela-Soto, E.M. Inactivation of porcine kidney betaine aldehyde dehydrogenase by hydrogen peroxide. Chem.-Biol. Interact., 2011, 191, 159-164.

[94] Slavica, A.; Dib, I.; Nidetzky, B. Single-site oxidation, cysteine 108 to cysteine sulfinic acid, in D-amino acid oxidase from Trigonopsis variabilis and its structural and functional consequences. Appl. Environ. Microbiol., 2005, 71, 8061-8068.

[95] Levine, R.L. Oxidative modification of glutamine synthetase. II. Characterization of the ascorbate model system. J. Biol. Chem., 1983, 258, $11828-11833$

[96] Rivett, A.J.; Roseman, J.E.; Oliver, C.N.; Levine, R.L.; Stadtman, E.R. Covalent modification of proteins by mixed-function oxidation: recognition by intracellular proteases. Prog. Clin. Biol. Res., 1985, 180, 317-328.

[97] Fucci, L.; Oliver, C.N.; Coon, M.J.; Stadtman, E.R. Inactivation of key metabolic enzymes by mixed function oxidation reactions: possible implication in protein turnover and ageing. Proc. Natl. Acad. Sci. U. S. A., 1983, 80, 1521-1525.

[98] Stadtman, E.R.; Berlett, B.S.; Chock, P.B. Manganese-dependent disproportionation of hydrogen peroxide in bicarbonate buffer. Proc. Natl. Acad. Sci. U. S. A., 1990, 87, 384-388.

[99] Farber, J.M.; Levine, R.L. Sequence of a peptide susceptible to mixed-function oxidation. Probable cation binding site in glutamine synthetase. J. Biol. Chem., 1986, 261, 4574-4578. 
[100] Climent, I.; Tsai, L.; Levine, R.L. Derivatization of $\gamma$-glutamyl semialdehyde residues in oxidized proteins by fluoresceinamine. Anal. Biochem., 1989, 182, 226-232.

[101] Sahakian, J.A.; Szweda, L.I.; Friguet, B.; Kitani, K.; Levine, R.L. Aging of the liver: Proteolysis of oxidatively modified glutamine synthetase. Arch. Biochem. Biophys., 1995, 318, 411-417.

[102] Fernandes, S.P.; Dringen, R.; Lawen, A.; Robinson, S.R. Inactivation of astrocytic glutamine synthetase by hydrogen peroxide requires iron. Neurosci. Lett., 2011, 490, 27-30.

[103] Garrison, W.M. Reaction mechanisms in the radiolysis of peptides, polypeptides, and proteins. Chem. Rev., 1987, 87, 381-398.

[104] Schuessler, H.; Schilling, K. Oxygen effect in the radiolysis of proteins. Part 2 bovine serum albumin. Int. J. Radiat. Biol., 1984, 45, 267281.

[105] Uchida, K.; Kato, Y.; Kawakishi, S. A novel mechanism for oxidative cleavage of prolyl peptides induced by the hydroxyl radical. Biochem. Biophys. Res. Commun., 1990, 169, 265-271.

[106] Zhou, J.Q.; Gafni, A. Exposure of rat muscle phosphoglycerate kinase to a nonenzymatic MFO system generates the old form of the enzyme. J. Gerontol., 1991, 46, B217-B221.

[107] Brodie, A.E.; Reed, D.J. Cellular recovery of glyceraldehyde-3-phosphate dehydrogenase activity and thiol status after exposure to hydroperoxides. Arch. Biochem. Biophys., 1990, 276, 212-218.

[108] Takahashi, R.; Goto, S. Alteration of aminoacyl-tRNA synthetase with age: Heat-labilization of the enzyme by oxidative damage. Arch. Biochem. Biophys., 1990, 277, 228-233.

[109] Verzijl, N.; DeGroot, J.; Oldehinkel, E.; Bank, R.A.; Thorpe, S.R.; Baynes, J.W.; Bayliss, M.T.; Bijlsma, J.W.J.; Lafeber, F.P.J.G.; TeKoppele, J.M. Age-related accumulation of Maillard reaction products in human articular cartilage collagen. Biochem. J., 2000, 350, 381-387. [110] Wells-Knecht, K.J.; Zyzak, D.V.; Litchfield, J.E.; Thorpe, S.R.; Baynes, J.W. Mechanism of autoxidative glycosylation: Identification of glyoxal and arabinose as intermediates in the autoxidative modification of proteins by glucose. Biochemistry, 1995, 34, 3702-3709.

[111] Uchida, K.; Stadtman, E.R. Covalent attachment of 4-hydroxynonenal to glyceraldehyde-3-phosphate dehydrogenase. A possible involvement of intra- and intermolecular cross- linking reaction. J. Biol. Chem., 1993, 268, 6388-6393.

[112] Friguet, B.; Stadtman, E.R.; Szweda, L.I. Modification of glucose-6-phosphate dehydrogenase by 4-hydroxy-2-nonenal. Formation of cross-linked protein that inhibits the multicatalytic protease. J. Biol. Chem., 1994, 269, 21639-21643.

[113] Do, D.D.; Weiland, R.H. Consistency between rate expressions for enzyme reactions and deactivation. Biotechnol. Bioeng., 1980, 22, 1087-1093.

[114] Grubecki, I. Optimal temperature control in a batch bioreactor with parallel deactivation of enzyme. J. Process Control, 2010, 20, 573584.

[115] Andersen, V.S. On hydrogen peroxide decomposition; ferric salt catalysis. Acta Chem. Scand., 2, 1-13.

[116] Welkie, G.W. Cobalt inhibition of iron-catalyzed hydrogen peroxide decomposition of riboflavin. Biochim. Biophys. Acta, Gen. Subj., 1968, 158, 479-481.

[117] Huang, H.H.; Lu, M.C.; Chen, J.N. Catalytic decomposition of hydrogen peroxide and 2-chlorophenol with iron oxides. Water Res., 2001, 35, 2291-2299.

[118] Turkevich, J.; Miner-Jr, R.S.; Okura, I.; Namba, S.; Zacharina, N. In 12th Swedish Symposium on Catalysis: Lund, 1981, pp 111-222.

[119] Kanungo, S.B. Physicochemical properties of $\mathrm{MnO}_{2}$ and $\mathrm{MnO}_{2}-\mathrm{CuO}$ and their relationship with the catalytic activity for $\mathrm{H}_{2} \mathrm{O}_{2}$ decomposition and CO oxidation. J. Catal., 1979, 58, 419-435.

[120] Hasnat, M.A.; Rahman, M.M.; Borhanuddin, S.M.; Siddiqua, A.; Bahadur, N.M.; Karim, M.R. Efficient hydrogen peroxide decomposition on bimetallic Pt-Pd surfaces. Catal. Commun., 2010, 12, 286-291. 
[121] Fanelli, E.; Turco, M.; Russo, A.; Bagnasco, G.; Marchese, S.; Pernice, P.; Aronne, A. $\mathrm{MnO}_{\mathrm{x}} / \mathrm{ZrO}_{2}$ gel-derived materials for hydrogen peroxide decomposition. J. Sol-Gel Sci. Technol., 2011, 60, 426-436.

[122] Soleymani, M.; Moheb, A.; Babakhani, D. Hydrogen Peroxide Decomposition over Nanosized $\operatorname{La}_{1-\mathrm{X}} \mathrm{Ca}_{\mathrm{X}} \mathrm{MnO}_{3}(0 \leq \mathrm{X} \leq 0.6) \mathrm{Perovskite}$ Oxides. Chem. Eng. Technol., 2011, 34, 49-55.

[123] Naya, S.I.; Teranishi, M.; Kimura, K.; Tada, H. A strong support-effect on the catalytic activity of gold nanoparticles for hydrogen peroxide decomposition. Chem. Commun., 2011, 47, 3230-3232.

[124] Schussel, L.J.; Atwater, J.E. A continuous alcohol oxidase bioreactor for regenerative life support. Enzyme Microb. Technol., 1996, 18, 229-235.

[125] Vikartovská-Welwardová, A.; Michalková, E.; Gemeiner, P.; Welward, L. Stabilization of D-amino-acid oxidase from Trigonopsis variabilis by manganese dioxide. Folia Microbiol., 1999, 44, 380-384.

[126] Bao, J.; Koumatsu, K.; Furumoto, K.; Yoshimoto, M.; Fukunaga, K.; Nakao, K. Deactivation kinetics of immobilized glucose oxidase for production of calcium gluconate in an external loop airlift bioreactor. Biochem. Eng. J., 2004, 22, 33-41.

[127] Ibrahim, M.; Schlegel, H.G. Efficiency of bovine liver catalase as a catalyst to cleave $\mathrm{H}_{2} \mathrm{O}_{2}$ added continually to buffer solutions. Biotechnol. Bioeng., 1980, 22, 1895-1906.

[128] Fernandez-Lafuente, R. Stabilization of multimeric enzymes: Strategies to prevent subunit dissociation. Enzyme Microb. Technol., 2009, 45, 405-418.

[129] Signorella, S.; Hureau, C. Bioinspired functional mimics of the manganese catalases. Coord. Chem. Rev., 2012, 256, 1229-1245.

[130] Vlasits, J.; Jakopitsch, C.; Bernroitner, M.; Zamocky, M.; Furtmüller, P.G.; Obinger, C. Mechanisms of catalase activity of heme peroxidases. Arch. Biochem. Biophys., 2010, 500, 74-81.

[131] Chelikani, P.; Fita, I.; Loewen, P.C. Diversity of structures and properties among catalases. Cell. Mol. Life Sci., 2004, 61, $192-208$.

[132] Scott, D. Glucose conversion in preparation of albumen solids by glucose oxidase-catalase system. Agric. Food Chem., 1953, 1, 727-730.

[133] Maria, G.; Ene, M.D.; Jipa, I. Modelling enzymatic oxidation of d-glucose with pyranose 2-oxidase in the presence of catalase. J. Mol. Catal. B: Enzym., 2012, 74, 209-218.

[134] Tarhan, L.; Telefoncu, A. Characterization of immobilized glucose oxidase-catalase and their deactivation in a fluid-bed reactor. Appl. Biochem. Biotechnol., 1990, 26, 45-57.

[135] Tse, P.H.S.; Leypoldt, J.K.; Gough, D.A. Determination of the intrinsic kinetic constants of immobilized glucose oxidase and catalase. Biotechnol. Bioeng., 1987, 29, 696-704.

[136] Tse, P.H.S.; Gough, D.A. Time-dependent inactivation of immobilized glucose oxidase and catalase. Biotechnol. Bioeng., 1987, 29, 705713.

[137] Pifferi, P.G.; Ricci, G.; Poli, G.; Ruggeri, O.; Vaccari, A. Stability of glucose oxidase and catalase adsorbed on variously activated 13x zeolite. Biotechnol. Bioeng., 1982, 24, 2155-2165.

[138] Fukushima, S.; Uyama, A.; Katayama, S. Oxygen absorption accompanying enzymic reaction - oxidation of d-glucose in the presence of glucose oxidase and catalase. J. Chem. Eng. Jpn., 1978, 11, 227-233.

[139] Buchholz, K.; Goedelmann, B. Macrokinetics and operational stability of immobilized glucose oxidase and catalase. Biotechnol. Bioeng., 1978, 20, 1201-1220.

[140] Bouin, J.C.; Atallah, M.T.; Hultin, H.O. Relative efficiencies of a soluble and immobilized two enzyme system of glucose oxidase and catalase. Biochim. Biophys. Acta, 1976, 438, 23-36.

[141] Messing, R.A. Simultaneously immobilized glucose oxidase and catalase in controlled pore titania. Biotechnol. Bioeng., 1974, 16, 897908. 
[142] Priputina, L.S.; Obbarius, I.D.; Nikol'skaia, E.A. Effect of glucose oxidase and catalase preparations used in the food industry on experimental animals. Vopr. Pitan., 1971, 30, 39-42.

[143] Ozyilmaz, G.; Seyhan Tukel, S. Simultaneous and sequential co-immobilization of glucose oxidase and catalase onto florisil. J. Microbiol. Biotechnol., 2007, 17, 960-967.

[144] Ozyilmaz, G.; Tukel, S.S. Simultaneous co-immobilization of glucose oxidase and catalase in their substrates. Applied Biochemistry and Microbiology, 2007, 43, 29-35.

[145] Bankar, S.B.; Bule, M.V.; Singhal, R.S.; Ananthanarayan, L.A. Co-immobilization of glucose oxidase-catalase: Optimization of immobilization parameters to improve the immobilization yield. Int. J. Food Eng., 2011, 7.

[146] Godjevargova, T.; Dayal, R.; Marinov, I. Simultaneous covalent immobilization of glucose oxidase and catalase onto chemically modified acrylonitrile copolymer membranes. J. Appl. Polym. Sci., 2004, 91, 4057-4063.

[147] Dayal, R.; Godjevargova, T. Pore diffusion studies with immobilized glucose oxidase plus catalase membranes. Enzyme Microb. Technol., 2006, 39, 1313-1318

[148] Godjevargova, T.; Dayal, R.; Turmanova, S. Gluconic acid production in bioreactor with immobilized glucose oxidase plus catalase on polymer membrane adjacent to anion-exchange membrane. Macromol. Biosci., 2004, 4, 950-956.

[149] Romero, L.E.; Cantero, D. Study of the deactivation process of the glucose oxidase-catalase enzymatic system by means of simulation. Prog. Biotechnol., 1998, 15, 107-112.

[150] Sankaran, K.; Godbole, S.S.; D'Souza, S.F. Preparation of spray-dried, sugar-free egg powder using glucose oxidase and catalase coimmobilized on cotton cloth. Enzyme Microb. Technol., 1989, 11, 617-619.

[151] Yoshimoto, M.; Takaki, N.; Yamasaki, M. Catalase-conjugated liposomes encapsulating glucose oxidase for controlled oxidation of glucose with decomposition of hydrogen peroxide produced. Colloids Surf., B, 2010, 79, 403-408.

[152] Yoshimoto, M.; Miyazaki, Y.; Kudo, Y.; Fukunaga, K.; Nakao, K. Glucose oxidation catalyzed by liposomal glucose oxidase in the presence of catalase-containing liposomes. Biotechnol. Prog., 2006, 22, 704-709.

[153] Yoshimoto, M.; Wang, S.; Fukunaga, K.; Fournier, D.; Walde, P.; Kuboi, R.; Nakao, K. Novel immobilized liposomal glucose oxidase system using the channel protein OmpF and catalase. Biotechnol. Bioeng., 2005, 90, 231-238.

[154] Uppoor, R.; Niebergall, P.J. $\beta-\mathrm{D}(+)$ glucose-glucose oxidase-catalase for use as an antioxidant system. Pharm. Dev. Technol., 1996, 1, 127-134.

[155] Min, S.; Mistry, B.S.; Lee, H.O. Improvement of oxidative and emulsion stability of model salad dressing by glucose oxidase-catalase. J. Food Sci., 2003, 68, 1272-1275.

[156] Isaksen, A.; Adler-Nissen, J. Antioxidative Effect of Glucose Oxidase and Catalase in Mayonnaises of Different Oxidative Susceptibility. I. Product Trials. LWT - Food Sci. Technol., 1997, 30, 841-846.

[157] Isaksen, A.; Adler-Nissen, J. Antioxidative Effect of Glucose Oxidase and Catalase in Mayonnaises of Different Oxidative Susceptibility. II. Mathematical Modelling. LWT - Food Sci. Technol., 1997, 30, 847-852.

[158] Castellari, M.; Matricardi, L.; Arfelli, G.; Carpi, G.; Galassi, S. Effects of high hydrostatic pressure processing and of glucose oxidasecatalase addition on the color stability and sensorial score of grape juice. Food Sci. Technol. Int., 2000, 6, 17-23.

[159] Dey, E.S.; Flygare, S.; Mosbach, K. Stabilization of d-amino acid oxidase from yeast Trigonopsis variabilis used for production of glutaryl-7-aminocephalosporanic acid from cephalosporin C. Appl. Biochem. Biotechnol., 1991, 27, $239-250$.

[160] Lopez-Gallego, F.; Batencor, L.; Hidalgo, A.; Mateo, C.; Fernandez-Lafuente, R.; Guisan, J.M. One-pot conversion of cephalosporin C to 7-aminocephalosporanic acid in the absence of hydrogen peroxide. Adv. Synth. Catal., 2005, 347, 1804-1810. 
[161] López-Gallego, F.; Betancor, L.; Sio, C.F.; Reis, C.R.; Jimenez, P.N.; Guisan, J.M.; Quax, W.J.; Fernandez-Lafuente, R. Evaluation of different glutaryl acylase mutants to improve the hydolysis of cephalosporin C in the absence of hydrogen peroxide. Adv. Synth. Catal., 2008, 350, 343-348.

[162] Garcia-Galan, C.; Berenguer-Murcia, A.; Fernandez-Lafuente, R.; Rodrigues, R.C. Potential of different enzyme immobilization strategies to improve enzyme performance. Adv. Synth. Catal., 2011, 353, 2885-2904.

[163] Trost, E.M.; Fischer, L. Minimization of by-product formation during D-amino acid oxidase catalyzed racemate resolution of D/L-amino acids. J. Mol. Catal. B: Enzym., 2002, 19-20, 189-195.

[164] Fernández-Lafuente, R.; Rodriguez, V.; Guisán, J.M. The coimmobilization of D-amino acid oxidase and catalase enables the quantitative transformation of D-amino acids (D-phenylalanine) into $\alpha$-keto acids (phenylpyruvic acid). Enzyme Microb. Technol., 1998, 23, 28-33.

[165] Tan, Q.; Song, Q.; Zhang, Y.; Wei, D. Characterization and application of D-amino acid oxidase and catalase within permeabilized pichia pastoris cells in bioconversions. Appl. Biochem. Biotechnol., 2007, 136, 279-289.

[166] Upadhya, R.; Nagajyothi; Bhat, S.G. Stabilization of D-amino acid oxidase and catalase in permeabilized Rhodotorula gracilis cells and its application for the preparation of $\alpha$-ketoacids. Biotechnol. Bioeng., 2000, 68, 430-436.

[167] Upadhya, R.; Nagajyothi, H.; Bhat, S.G. D-amino acid oxidase and catalase of detergent permeabilized Rhodotorula gracilis cells and its potential use for the synthesis of $\alpha$-keto acids. Process Biochem., 1999, 35, 7-13.

[168] Chung, S.Y.; Swaisgood, H.E.; Catignani, G.L. Measurement of amino acid racemization in alkali-treated proteins using an immobilized D-amino acid oxidase-catalase reactor. J. Agric. Food Chem., 1985, 33, 201-204.

[169] Miyaji, A.; Suzuki, M.; Baba, T.; Kamachi, T.; Okura, I. Hydrogen peroxide as an effecter on the inactivation of particulate methane monooxygenase under aerobic conditions. J. Mol. Catal. B: Enzym., 2009, 57, 211-215.

[170] Sukyai, P.; Rezić, T.; Lorenz, C.; Mueangtoom, K.; Lorenz, W.; Haltrich, D.; Ludwig, R. Comparing soluble and co-immobilized catalysts for 2-ketoaldose production by pyranose 2-oxidase and auxiliary enzymes. J. Biotechnol., 2008, 135, 281-290.

[171] Nordkvist, M.; Nielsen, P.M.; Villadsen, J. Oxidation of lactose to lactobionic acid by a Microdochium nivale carbohydrate oxidase: Kinetics and operational stability. Biotechnol. Bioeng., 2007, 97, 694-707.

[172] Hua, L.; Nordkvist, M.; Nielsen, P.M.; Villadsen, J. Scale-up of enzymatic production of lactobionic acid using the rotary jet head system. Biotechnol. Bioeng., 2007, 97, 842-849.

[173] Barlow, J.N.; Zhang, Z.; John, P.; Baldwin, J.E.; Schofield, C.J. Inactivation of 1-aminocyclopropane-1-carboxylate oxidase involves oxidative modifications. Biochemistry, 1997, 36, 3563-3569.

[174] Ostuni, M.A.; Bizouarn, T.; Baciou, L.; Houée-Levin, C. Modulation of the activity of the NADPH oxidase system by reactive oxygen species: Influence of catalase. Radiat. Prot. Dosim., 2011, 143, 166-171.

[175] Seip, J.E.; Fager, S.K.; Gavagan, J.E.; Anton, D.L.; Di Cosimo, R. Glyoxylic acid production using immobilized glycolate oxidase and catalase. Bioorg. Med. Chem., 1994, 2, 371-378.

[176] Ramakrishnan, V.; Lathika, K.M.; D'Souza, S.J.; Singh, B.B.; Raghavan, K.G. Investigation with chitosan-oxalate oxidase-catalase conjugate for degrading oxalate from hyperoxaluric rat chyme. Indian J. Biochem. Biophys., 1997, 34, 373-378.

[177] Mizuno, S.; Imada, Y. Conversion of methanol to formic acid through the coupling of the enzyme reactions of alcohol oxidase, catalase and formaldehyde dismutase. Biotechnol. Lett., 1986, 8, 79-84.

[178] Ukeda, H.; Ishii, T.; Sawamura, M.; Isobe, K. Glycolaldehyde Production from Ethylene Glycol with Immobilized Alcohol Oxidase and Catalase. Biosci. Biotechnol. Biochem., 1998, 62, 1589-1591.

[179] Krämer, L.; Steckhan, E. Coimmobilization of L- $\alpha$-glycerophosphate oxidase with catalase and its application for the synthesis of dihydroxyacetone phosphate. Tetrahedron, 1997, 53, 14645-14650. 
[180] Tramper, J.; Muller, F.; Van Der Plas, H.C. Immobilized xanthine oxidase: Kinetics, (in)stability, and stabilization by coimmobilization with superoxide dismutase and catalase. Biotechnol. Bioeng., 1978, 20, 1507-1522.

[181] Federici, F.; Petruccioli, M.; Piccioni, P. Glucose oxidase and catalase activities of Penicillium variabile P16 immobilized in polyurethane sponge. J. Ind. Microbiol., 1996, 17, 15-19.

[182] Gellissen, G.; Piontek, M.; Dahlems, U.; Jenzelewski, V.; Gavagan, J.E.; DiCosimo, R.; Anton, D.L.; Janowicz, Z.A. Recombinant Hansenula polymorpha as a biocatalyst: Coexpression of the spinach glycolate oxidase (GO) and the S. cerevisiae catalase T (CTT1) gene. Appl. Microbiol. Biotechnol., 1996, 46, 46-54.

[183] Deshpande, A.; D'Souza, S.F.; Nadkarni, G.B. Coimmobilization of D-amino acid oxidase and catalase by entrapment of Trigonopsis variabilis in radiation polymerised Polyacrylamide beads. J. Biosci., 1987, 11, 137-144.

[184] Petkov, L.; Sajdok, J.; Rae, K.; Šůchová, M.; Káš, J.; Turková, J. Activation of galactose-containing glycoprotein and solid supports by galactose oxidase in presence of catalase for immobilization purposes. Biotechnol. Tech., 1990, 4, 25-30.

[185] Ikawa, S.; Obara, T. Blood sugar determination using glucose oxidase-catalase. Rinsho Byori, 1965, 13, 197-200.

[186] Bowden, C.H. The estimation of blood galactose using a glucose oxidase-catalase reagent. J. Clin. Pathol., 1963, 16, 470-472.

[187] Tang, J.; Tang, D.; Li, Q.; Su, B.; Qiu, B.; Chen, G. Sensitive electrochemical immunoassay of carcinoembryonic antigen with signal dualamplification using glucose oxidase and an artificial catalase. Anal. Chim. Acta, 2011, 697, 16-22.

[188] Hnaien, M.; Lagarde, F.; Jaffrezic-Renault, N. A rapid and sensitive alcohol oxidase/catalase conductometric biosensor for alcohol determination. Talanta, 2010, 81, 222-227.

[189] Zuo, G.; Jiang, X.; Liu, H.; Zhang, J. A novel urinary oxalate determination method via a catalase model compound with oxalate oxidase. Anal. Methods, 2010, 2, 254-258.

[190] Leifheit, M.; Bergmann, W.; Greiser, J. Application of exchangeable biochemical reactors with oxidase-catalase-co-immobilizates and immobilized microorganisms in a microfluidic chip-calorimeter. Eng. Life Sci., 2008, 8, 540-545.

[191] Nadzhafova, O.Y.; Drozdova, M.V.; Symonenko, Y.M. Enzymatic determination of phenols in water using catalase and herbal extract of oxidases. Khim. Tekhnol. Vody, 2005, 27, 444-452.

[192] Kang, S.I.; Bae, Y.H. A sulfonamide based glucose-responsive hydrogel with covalently immobilized glucose oxidase and catalase. J. Controlled Release, 2003, 86, 115-121.

[193] Renneberg, R.; Pfeiffer, D.; Scheller, F.; Jänchen, M. Enzyme sequence and competition electrodes based on immobilized glucose oxidase, peroxidase and catalase. Anal. Chim. Acta, 1982, 134, 359-364.

[194] Liu, C.C.; Wingard Jr, L.B.; Wolfson Jr, S.K. Quantitation of glucose concentration using a glucose oxidase-catalase electrode by potentiometric measurement. Bioelectrochem. Bioenerg., 1979, 6, 19-26.

[195] Azevedo, A.M.; Cabral, J.M.S.; Prazeres, D.M.F.; Gibson, T.D.; Fonseca, L.P. Thermal and operational stabilities of Hansenula polymorpha alcohol oxidase. J. Mol. Catal. B: Enzym., 2004, 27, 37-45.

[196] Renirie, R.; Pierlot, C.; Aubry, J.M.; Hartog, A.F.; Schoemaker, H.E.; Alsters, P.L.; Wever, R. Vanadium Chloroperoxidase as a Catalyst for Hydrogen Peroxide Disproportionation to Singlet Oxygen in Mildly Acidic Aqueous Environment. Adv. Synth. Catal., 2003, 345, 849-858.

[197] Grey, C.E.; Rundbäck, F.; Adlercreutz, P. Improved operational stability of chloroperoxidase through use of antioxidants. J. Biotechnol., 2008, 135, 196-201.

[198] Pezzotti, F.; Okrasa, K.; Therisod, M. Oxidation of chlorophenols catalyzed by Coprinus cinereus peroxidase with in situ production of hydrogen peroxide. Biotechnol. Prog., 2004, 20, 1868-1871.

[199] Borole, A.; Dai, S.; Cheng, C.L.; Rodriguez Jr, M.; Davison, B.H. Performance of chloroperoxidase stabilization in mesoporous sol-gel glass using In Situ glucose oxidase peroxide generation. Appl. Biochem. Biotechnol., 2004, 113, 273-285. 
[200] Van Dongen, S.F.M.; Nallani, M.; Cornelissen, J.J.L.M.; Nolte, R.J.M.; Van Hest, J.C.M. A three-enzyme cascade reaction through positional assembly of enzymes in a polymersome nanoreactor. Chem. - Eur. J., 2009, 15, 1107-1114.

[201] Lee, M.Y.; Srinivasan, A.; Ku, B.; Dordick, J.S. Multienzyme catalysis in microfluidic biochips. Biotechnol. Bioeng., 2003, 83, 20-28.

[202] Ankudey, E.G.; Olivo, H.F.; Peeples, T.L. Lipase-mediated epoxidation utilizing urea-hydrogen peroxide in ethyl acetate. Green Chem., 2006, 8, 923-926.

[203] Bourdillon, C.; Hervagault, C.; Thomas, D. Increase in operational stability of immobilized glucose oxidase by the use of an artificial cosubstrate. Biotechnol. Bioeng., 1985, 27, 1619-1622.

[204] Tabatabaie, T.; Floyd, R.A. Susceptibility of glutathione peroxidase and glutathione reductase to oxidative damage and the protective effect of spin trapping agents. Arch. Biochem. Biophys., 1994, 314, 112-119.

[205] Van Deurzen, M.P.J.; Seelbach, K.; Van Rantwijk, F.; Kragl, U.; Sheldon, R.A. Chloroperoxidase: Use of a hydrogen peroxide-stat for controlling reactions and improving enzyme performance. Biocatal. Biotransform., 1997, 15, 1-16.

[206] Arnao, M.B.; Acosta, M.; Del Rio, J.A.; Carcia-Canovas, F. Inactivation of peroxidase by hydrogen peroxide and its protection by a reductant agent. Biochim. Biophys. Acta, Protein Struc. Mol. Enzymol., 1990, 1038, 85-89.

[207] Hossain, M.A.; Asada, K. Inactivation of ascorbate peroxidase in spinach chloroplasts on dark addition of hydrogen peroxide: Its protection by ascorbate. Plant Cell Physiol., 1984, 25, 1285-1295.

[208] Mahmoudi, A.; Nazari, K.; Khosraneh, M.; Mohajerani, B.; Kelay, V.; Moosavi-Movahedi, A.A. Can amino acids protect horseradish peroxidase against its suicide-peroxide substrate? Enzyme Microb. Technol., 2008, 43, 329-335.

[209] Collins, P.J.; Field, J.A.; Teunissen, P.; Dobson, A.D.W. Stabilization of lignin peroxidases in white rot fungi by tryptophan. Appl. Environ. Microbiol., 1997, 63, 2543-2548.

[210] Murakami, K.; Onoda, Y.; Kimura, J.; Yoshino, M. Protection by histidine against oxidative inactivation of AMP deaminase in yeast. Biochem. Mol. Biol. Int., 1997, 42, 1063-1069.

[211] Andersson, M.M.; Breccia, J.D.; Hatti-Kaul, R. Stabilizing effect of chemical additives against oxidation of lactate dehydrogenase. Biotechnol. Appl. Biochem., 2000, 32, 145-153.

[212] Bratkovskaja, I.; Vidziunaite, R.; Kulys, J. Oxidation of phenolic compounds by peroxidase in the presence of soluble polymers. Biochemistry (Moscow), 2004, 69, 985-992.

[213] DePaz, R.A.; Barnett, C.C.; Dale, D.A.; Carpenter, J.F.; Gaertner, A.L.; Randolph, T.W. The excluding effects of sucrose on a protein chemical degradation pathway: Methionine oxidation in subtilisin. Arch. Biochem. Biophys., 2000, 384, 123-132.

[214] Joo, H.S.; Koo, Y.M.; Choi, J.W.; Chang, C.S. Stabilization method of an alkaline protease from inactivation by heat, SDS and hydrogen peroxide. Enzyme Microb. Technol., 2005, 36, 766-772.

[215] Pérez-Gilabert, M.; Veldink, G.A.; Vliegenthart, J.F.G. Protection by different agents against inactivation of lipoxygenase by hydrogen peroxide. Lipids, 1996, 31, 1245-1250.

[216] Nazari, K.; Esmaeili, N.; Mahmoudi, A.; Rahimi, H.; Moosavi-Movahedi, A.A. Peroxidative phenol removal from aqueous solutions using activated peroxidase biocatalyst. Enzyme Microb. Technol., 2007, 41, 226-233.

[217] Valderrama, B.; Ayala, M.; Vazquez-Duhalt, R. Suicide inactivation of peroxidases and the challenge of engineering more robust enzymes. Chem. Biol., 2002, 9, 555-565.

[218] Gilles, A.M.; Marliere, P.; Rose, T.; Sarfati, R.; Longin, R.; Meier, A.; Fermandjian, S.; Monnot, M.; Cohen, G.N.; Barzu, O. Conservative replacement of methionine by norleucine in Escherichia coli adenylate kinase. J. Biol. Chem., 1988, 263, 8204-8209.

[219] Kim, Y.H.; Berry, A.H.; Spencer, D.S.; Stites, W.E. Comparing the effect on protein stability of methionine oxidation versus mutagenesis: Steps toward engineering oxidative resistance in proteins. Protein Eng., 2001, 14, 343-347. 
[220] Miyazaki, C.; Takahashi, H. Engineering of the $\mathrm{H}_{2} \mathrm{O}_{2}$-binding pocket region of a recombinant manganese peroxidase to be resistant to $\mathrm{H}_{2} \mathrm{O}_{2}$. FEBS Lett., 2001, 509, 111-114.

[221] Ogola, H.J.O.; Hashimoto, N.; Miyabe, S.; Ashida, H.; Ishikawa, T.; Shibata, H.; Sawa, Y. Enhancement of hydrogen peroxide stability of a novel Anabaena sp. DyP-type peroxidase by site-directed mutagenesis of methionine residues. Appl. Microbiol. Biotechnol., 2010, 87, 17271736.

[222] Roger Chien, H.C.; Hsu, C.L.; Hu, H.Y.; Wang, W.C.; Hsu, W.H. Enhancing oxidative resistance of Agrobacterium radiobacter Ncarbamoyl D-amino acid amidohydrolase by engineering solvent-accessible methionine residues. Biochem. Biophys. Res. Commun., 2002, 297, 282-287.

[223] Lin, L.L.; Lo, H.F.; Chiang, W.Y.; Hu, H.Y.; Hsu, W.H.; Chang, C.T. Replacement of methionine 208 in a truncated Bacillus sp. TS-23 $\alpha$ amylase with oxidation-resistant leucine enhances its resistance to hydrogen peroxide. Curr. Microbiol., 2003, 46, $211-216$.

[224] Kuo, L.Y.; Hwang, G.Y.; Yang, S.L.; Hua, Y.W.; Chen, W.; Lin, L.L. Inactivation of Bacillus stearothermophilus leucine aminopeptidase II by hydrogen peroxide and site-directed mutagenesis of methionine residues on the enzyme. Protein J., 2004, 23, $295-302$.

[225] Kitajima, S.; Kitamura, M.; Koja, N. Triple mutation of Cys26, Trp35, and Cys126 in stromal ascorbate peroxidase confers $\mathrm{H}_{2} \mathrm{O}_{2}$ tolerance comparable to that of the cytosolic isoform. Biochem. Biophys. Res. Commun., 2008, 372, 918-923.

[226] Shen, H.; Tsuchida, S.; Tamai, K.; Sato, K. Identification of cysteine residues involved in disulfide formation in the inactivation of glutathione transferase P-form by hydrogen peroxide. Arch. Biochem. Biophys., 1993, 300, 137-141.

[227] Gabbianelli, R.; Battistoni, A.; Capo, C.; Polticelli, F.; Rotilio, G.; Meier, B.; Desideri, A. Effect of Val $73 \rightarrow$ Trp mutation on the reaction of 'cambialistic' superoxide dismutase from Propionibacterium shermanii with hydrogen peroxide. Arch. Biochem. Biophys., 1997, 345, 156159.

[228] Gazaryan, I.G.; Chubar, T.A.; Ignatenko, O.V.; Mareeva, E.A.; Orlova, M.A.; Kapeliuch, Y.L.; Savitsky, P.A.; Rojkova, A.M.; Tishkov, V.I. Tryptophanless recombinant horseradish peroxidase: Stability and catalytic properties. Biochem. Biophys. Res. Commun., 1999, 262, 297301.

[229] Ryan, B.J.; Ó'Fágáin, C. Effects of single mutations on the stability of horseradish peroxidase to hydrogen peroxide. Biochimie, 2007, 89, 1029-1032.

[230] Koo, K.H.; Lee, S.; Jeong, S.Y.; Kim, E.T.; Kim, H.J.; Kim, K.; Song, K.; Chae, H.Z. Regulation of thioredoxin peroxidase activity by Cterminal truncation. Arch. Biochem. Biophys., 2002, 397, 312-318.

[231] Villegas, J.A.; Mauk, A.G.; Vazquez-Duhalt, R. A cytochrome c variant resistant to heme degradation by hydrogen peroxide. Chem. Biol., 2000, 7, 237-244.

[232] Zámocký, M.; Koller, F. Understanding the structure and function of catalases: Clues from molecular evolution and in vitro mutagenesis. Prog. Biophys. Mol. Biol., 1999, 72, 19-66.

[233] Bornscheuer, U.T.; Pohl, M. Improved biocatalysts by directed evolution and rational protein design. Curr. Opin. Chem. Biol., 2001, 5, 137-143.

[234] Turner, N.J. Directed evolution drives the next generation of biocatalysts. Nat. Chem. Biol., 2009, 5, 567-573.

[235] Takahashit, H.; Miyazaki-Imamura, C. New strategies for enzyme stabilization involving molecular evolution and immobilization in mesoporous materials. e-Journal of Surface Science and Nanotechnology, 2005, 3.

[236] Langsch, A.; Bader, A. Functional expression and stabilization of horseradish peroxidase by directed evolution in Saccharomyces cerevisiae. Biotechnol. Bioeng., 2001, 76, 99-107.

[237] Cherry, J.R.; Lamsa, M.H.; Schneider, P.; Vind, J.; Svendsen, A.; Jones, A.; Pedersen, A.H. Directed evolution of a fungal peroxidase. Nat. Biotechnol., 1999, 17, 379-384. 
[238] Rodrigues, R.C.; Berenguer-Murcia, Á.; Fernandez-Lafuente, R. Coupling chemical modification and immobilization to improve the catalytic performance of enzymes. Adv. Synth. Catal., 2011, 353, 2216-2238.

[239] Mateo, C.; Palomo, J.M.; Fernandez-Lorente, G.; Guisan, J.M.; Fernandez-Lafuente, R. Improvement of enzyme activity, stability and selectivity via immobilization techniques. Enzyme Microb. Technol., 2007, 40, 1451-1463.

[240] Sun, S.; Yang, G.; Bi, Y.; Liang, H. Enzymatic epoxidation of corn oil by perstearic acid. J. Am. Oil Chem. Soc., 2011, 88, $1567-1571$.

[241] Kotlewska, A.J.; Van Rantwijk, F.; Sheldon, R.A.; Arends, I.W.C.E. Epoxidation and Baeyer-Villiger oxidation using hydrogen peroxide and a lipase dissolved in ionic liquids. Green Chem., 2011, 13, 2154-2160.

[242] Bitencourt, T.B.; Da Graça Nascimento, M. The influence of organic solvent and ionic liquids on the selective formation of 2-(2ethylhexyl)-3-phenyl-1,2-oxaziridine mediated by lipases. J. Phys. Org. Chem., 2010, 23, 995-999.

[243] Sharma, U.K.; Sharma, N.; Kumar, R.; Sinha, A.K. Biocatalytic promiscuity of lipase in chemoselective oxidation of aryl alcohols/acetates: a unique synergism of cal-b and [hmim]br for the metal-free $\mathrm{H}_{2} \mathrm{O}_{2}$ activation. Org. Lett., 2009, 11, 4846-4848.

[244] Svedendahl, M.; Carlqvist, P.; Branneby, C.; Allnér, O.; Frise, A.; Hult, K.; Berglund, P.; Brinck, T. Direct epoxidation in Candida antarctica lipase B studied by experiment and theory. ChemBioChem, 2008, 9, 2443-2451.

[245] Tiran, C.; Lecomte, J.; Dubreucq, E.; Villeneuve, P. Chemo-enzymatic epoxidation of fatty compounds - Focus on processes involving a lipase-catalyzed perhydrolysis step. OCL - Ol. Corps Gras Li., 2008, 15, 179-183.

[246] Törnvall, U.; Orellana-Coca, C.; Hatti-Kaul, R.; Adlercreutz, D. Stability of immobilized Candida antarctica lipase B during chemoenzymatic epoxidation of fatty acids. Enzyme Microb. Technol., 2007, 40, 447-451.

[247] Törnvall, U.; Fürst, C.M.; Hatti-Kaul, R.; Hedström, M. Mass spectrometric analysis of peptides from an immobilized lipase: Focus on oxidative modifications. Rapid Commun. Mass Spectrom., 2009, 23, 2959-2964.

[248] Tzialla, A.A.; Pavlidis, I.V.; Felicissimo, M.P.; Rudolf, P.; Gournis, D.; Stamatis, H. Lipase immobilization on smectite nanoclays: Characterization and application to the epoxidation of $\alpha$-pinene. Bioresour. Technol., 2010, 101, 1587-1594.

[249] Hernandez, K.; Fernandez-Lafuente, R. Lipase B from Candida antarctica immobilized on octadecyl Sepabeads: A very stable biocatalyst in the presence of hydrogen peroxide. Process Biochem., 2011, 46, 873-878.

[250] Hernandez, K.; Garcia-Galan, C.; Fernandez-Lafuente, R. Simple and efficient immobilization of lipase B from Candida antarctica on porous styrene-divinylbenzene beads. Enzyme Microb. Technol., 2011, 49, 72-78.

[251] Fernández-Lafuente, R.; Rodríguez, V.; Mateo, C.; Fernández-Lorente, G.; Arminsen, P.; Sabuquillo, P.; Guisán, J.M. Stabilization of enzymes (D-amino acid oxidase) against hydrogen peroxide via immobilization and post-immobilization techniques. J. Mol. Catal. B: Enzym., 1999, 7, 173-179.

[252] Lloyd, C.R.; Eyring, E.M. Protecting heme enzyme peroxidase activity from $\mathrm{H}_{2} \mathrm{O}_{2}$ inactivation by sol-gel encapsulation. Langmuir, 2000, 16, 9092-9094.

[253] Kuan, I.C.; Wu, J.C.; Lee, S.L.; Tsai, C.W.; Chuang, C.A.; Yu, C.Y. Stabilization of d-amino acid oxidase from Rhodosporidium toruloides by encapsulation in polyallylamine-mediated biomimetic silica. Biochem. Eng. J., 2010, 49, 408-413.

[254] Hsieh, H.C.; Kuan, I.C.; Lee, S.L.; Tien, G.Y.; Wang, Y.J.; Yu, C.Y. Stabilization of d-amino acid oxidase from Rhodosporidium toruloides by immobilization onto magnetic nanoparticles. Biotechnol. Lett., 2009, 31, 557-563.

[255] Betancor, L.; Hidalgo, A.; Fernández-Lorente, G.; Mateo, C.; Rodríguez, V.; Fuentes, M.; López-Gallego, F.; Fernández-Lafuente, R.; Guisan, J.M. Use of physicochemical tools to determine the choice of optimal enzyme: Stabilization of D-amino acid oxidase. Biotechnol. Prog., 2003, 19, 784-788.

[256] Betancor, L.; López-Gallego, F.; Hidalgo, A.; Alonso-Morales, N.; Dellamora-Ortiz, G.; Guisán, J.M.; Fernández-Lafuente, R. Preparation of a very stable immobilized biocatalyst of glucose oxidase from Aspergillus niger. J. Biotechnol., 2006, 121, 284-289. 
[257] Bódalo, A.; Bastida, J.; Máximo, M.F.; Montiel, M.C.; Gómez, M.; Murcia, M.D. A comparative study of free and immobilized soybean and horseradish peroxidases for 4-chlorophenol removal: Protective effects of immobilization. Bioprocess Biosyst. Eng., 2008, 31, 587-593.

[258] Gómez, J.L.; Bódalo, A.; Gómez, E.; Bastida, J.; Hidalgo, A.M.; Gómez, M. Immobilization of peroxidases on glass beads: An improved alternative for phenol removal. Enzyme Microb. Technol., 2006, 39, 1016-1022.

[259] Chiumiento, A.; Lamponi, S.; Barbucci, R.; Dominguez, A.; Perez, Y.; Villalonga, R. Immobilizing Cu,Zn-superoxide dismutase in hydrogels of carboxymethylcellulose improves its stability and wound healing properties. Biochemistry (Moscow), 2006, 71, 1324-1328.

[260] Hernandez, K.; Fernandez-Lafuente, R. Control of protein immobilization: Coupling immobilization and site-directed mutagenesis to improve biocatalyst or biosensor performance. Enzyme Microb. Technol., 2011, 48, 107-122.

[261] Baslé, E.; Joubert, N.; Pucheault, M. Protein Chemical Modification on Endogenous Amino Acids. Chem. Biol., 2010, 17, $213-227$.

[262] Zakharova, G.S.; Uporov, I.V.; Tishkov, V.I. Horseradish peroxidase: Modulation of properties by chemical modification of protein and heme. Biochemistry (Moscow), 2011, 76, 1391-1401.

[263] Kojima, Y.; Akaike, T.; Sato, K.; Maeda, H.; Hirano, T. Polymer conjugation to Cu,Zn-SOD and suppression of hydroxyl radical generation on exposure to $\mathrm{H}_{2} \mathrm{O}_{2}$ : Improved stability of SOD in vitro and in vivo. J. Bioact. Compat. Polym., 1996, 11, 169-190.

[264] Valdivia, A.; Perez, Y.; Dominguez, A.; Caballero, J.; Gomez, L.; Schacht, E.H.; Villalonga, R. Improved anti-inflammatory and pharmacokinetic properties for superoxide dismutase by chemical glycosidation with carboxymethylchitin. Macromol. Biosci., 2005, 5, 118-123. [265] Valdivia, A.; Pérez, Y.; Cao, R.; Baños, M.; García, A.; Villalonga, R. Bienzymatic supramolecular complex of catalase modified with cyclodextrin-branched carboxymethylcellulose and superoxide dismutase: Stability and anti-inflammatory properties. Macromol. Biosci., 2007, 7, 70-75.

[266] Eryomin, A.N.; Litvinchuk, A.V.; Metelitza, D.I. Operational stability of catalase and its conjugates with aldehyde dextrans and superoxide dismutase. Biochemistry (Moscow), 1996, 61, 483-494.

[267] Cowan, D.A.; Fernandez-Lafuente, R. Enhancing the functional properties of thermophilic enzymes by chemical modification and immobilization. Enzyme Microb. Technol., 2011, 49, 326-346. 
Figure Legends

Figure 1. Chemical modification of proteins by hydrogen peroxide.

A-Oxidation of amino acid residues in proteins. a-Oxidation of histidine residues. b,e,j Aromatic aminoacid oxidation. c,i-Sulfur amino acid oxidation. d-Proline oxidation, f-Threonine oxidation, g-Leucine oxidation, h-Lysine oxidation and formation of Amadori product (glycoxidation reaction).

B- Example of cleavage of the polypeptide chain. a-Cleavage by oxidation of prolyl residues. bCleavage by oxidation of aspartyl residues.

Figure 2. Schematic representation of the advantages of co-immobilization versus individual immobilization of oxidases and catalase in the in situ destruction of hydrogen peroxide.

Figure 3. Tricks to maintain low concentrations of hydrogen peroxide along the reaction.

Figure 4. Stabilization of an enzyme vesus hydrogen peroxide inactivation by immobilization on a hydrophophic support: generation of a hydrophobic environment around the sensitive groups.

Figure 5. Stabilization of an enzyme vesus hydrogen peroxide inactivation by multipoint covalent immobilization: susceptible group is buried inside the enzyme core and only may be exposed to hydrogen peroxide after enzyme conformational changes.

Figure 6. Stabilization of an enzyme vesus hydrogen peroxide inactivation by multipoint covalent immobilization: the modified enzyme is less stable but multipoint covalent attachment avoids enzyme conformational chanhe.

Figure 7. Stabilization of an enzyme vesus hydrogen peroxide inactivation by shielding the sensitive groiups versus the support surface.

Figure 8. Stabilization of an enzyme vesus hydrogen peroxide inactivation by chemical modification with a metal scavenging polymer.

Figure 9. Stabilization of an immobilized enzyme vesus hydrogen peroxide inactivation by generation of an hydrophohic environment using a hydrophobic polymer. 